\title{
Undenatured Type II Collagen (UC-II) in Joint Health and Disease: A Review on the Current Knowledge of Companion Animals
}

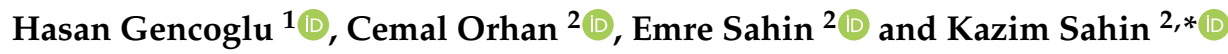 \\ 1 Department of Biology, Faculty of Science, Firat University, Elazig (+90) 424, Turkey; hgencoglu@firat.edu.tr \\ 2 Department of Animal Nutrition, Faculty of Veterinary Medicine, Firat University, Elazig (+90) 424, Turkey; \\ corhan@firat.edu.tr (C.O.); esahin@bingol.edu.tr (E.S.) \\ * Correspondence: nsahinkm@yahoo.com; Tel.: +90-532-7473506
}

Received: 4 March 2020; Accepted: 6 April 2020; Published: 17 April 2020

check for updates

Simple Summary: Osteoarthritis $(\mathrm{OA})$, the most common joint disease affecting humans and animals, is a painful, degenerative, and inflammatory disease that affects synovial joints and ultimately leads to loss of mobility. Non-pharmacological preventive approaches, several pharmaceutical therapeutic agents, and some medicines may reduce the progression of OA in animals. Many clinical and experimental studies have revealed that the undenatured form of type II collagen (UC-II) offers common health benefits to patients with OA.

\begin{abstract}
OA is quite common in companion animals, especially in large breed dogs and horses. Collagen, the most abundant protein of mammals, has specific connective tissue types for skin, bones, reticulate, basal lamina, bones, cell surfaces, while type II collagen (UC-II) forms the main structure of cartilage tissue. Even at the smaller dosages, UC-II has also been reported to be more effective than the glucosamine and chondroitin sulfate supplements, which are the supplements most frequently used in the market. In this review, we summarize the effects of UC-II on joint health and function in health and disease conditions in companion animals.
\end{abstract}

Keywords: collagen; inflammation; joint degeneration; osteoarthritis; pain

\section{Introduction}

Osteoarthritis (OA), also known as a degenerative joint illness, is a chronic, painful, and inflammatory disease that affects the joints in knees, feet, hips, spine, subchondral bone, synovial membranes, and periarticular tissues, and leads to immobility and morbidity in humans, dogs, horses, and cats, and companion animals throughout the world [1-3]. It is characterized by chronic joint pain, stiffness, inflexibility, swelling, narrowing of joint spaces, and formation of osteophytes and lameness [1-6]. Mobility reduction and pain caused by OA have a negative effect on the quality of life, comfort level, walking, exercise tolerance, activity, urinary and fecal habits behavior in animals [6-8]. It is known that nearly $20 \%$ of canine pets spontaneously develop osteoarthritis, and this translates to at least 15 million dogs in the USA alone [6]. OA mostly affects the large breed dogs [9], geriatric cats [10], and sport horses [11]. OA occurs in the dog populations mostly because of overweight and/or obesity, insufficient exercise, injury, becoming old, having an infection, immune disorders, or genetic predisposition [12]. Dogs also suffer more often with OA than immune-mediated arthritis [13]. Epidemiological studies have reported that risk factors for the development of OA comprise aging, excessive or non-physiological burdens, obesity, traumas, hormonal ailments, or a mixture of several factors [14-16]. Even though the exact etiology of the OA has not been identified yet, in the long 
run, articular cartilage degeneration results in changes to both as metabolisms of chondrocytes and synoviocytes such that inflammatory cytokines that are formed damage the ability of chondrocytes to renovate the cartilage matrix $[8,13,17]$.

The main goal in OA management in animals is to control clinical findings by protecting the joints from OA, reducing pain, increasing mobility, and, therefore, the quality of life [18]. For this purpose, non-pharmaceutical treatment options include surgery, weight loss, exercise modification, and physical therapy [19]. Surgical intervention or arthroplasty is frequently used to prevent joint changes or restore its function, but there have been no gold standards for both targets yet [8]. There are also pharmaceutical treatment options. For example, glucosamine, chondroitin, undenatured form of type II collagen, pentosane polysulphate, avocado/soybean unsaponifiables, green-lipped mussel, milk protein, creatine, and amino acid represent the largest category of natural supplements for veterinary medicine [16].

The undenatured form of type II collagen (UC-II), a nutritional supplement, is derived from chicken sternum cartilage and is a powdered, glycosylated, and shelf-resistant component [17]. Previous studies have revealed that UC-II reduced lameness after general pain, pain during limb manipulation, and physical exertion in arthritic dogs given $4 \mathrm{mg}$ or $40 \mathrm{mg}$ of UC-II daily [20]. Currently, only limited reviews on the effects of UC-II in animal OA have been published [21]. The aims of this review are to summarize the scientific data available in the literature on UC-II evaluated in animals, including dog, horse, and cat OA, and to discuss some studies about how to improve several aspects of research and issues with UC-II supplements, such as bioavailability and molecular mechanisms. In addition, companion animal studies related to UC-II are presented in this review for the purpose of being functional for veterinarians and animal owners.

\section{Molecular Factors in the OA Treatment}

Many candidate genes were identified as possible targets for the OA treatment, including a wide variety of molecules such as matrix metalloproteinases (MMPs), cytokines, cathepsin K, and caspases [22]. In OA, the extracellular matrix disintegrates in synovial joints, especially in the limbs, knees, and hips, as well as indicates severe pain in suffering individuals (Figure 1).

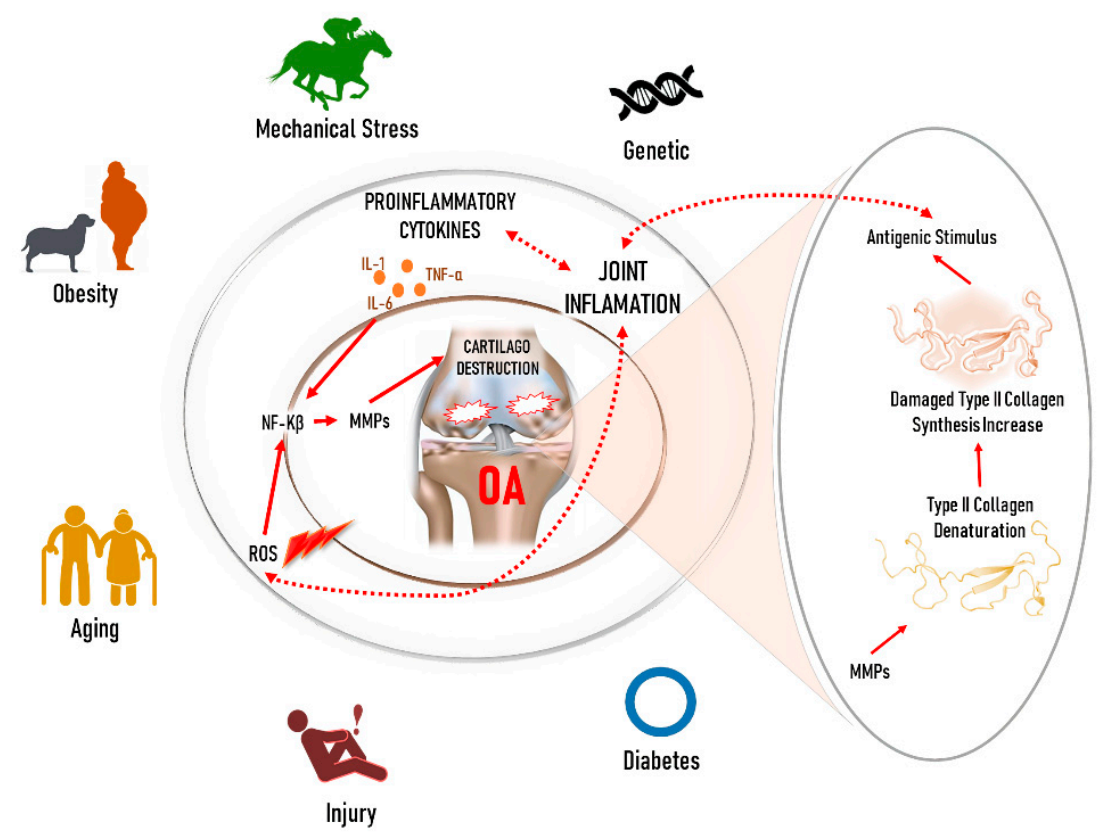

Figure 1. Schematic diagram of osteoarthritis; causes and inflammation mechanisms overview [23-28]. 
Joint and immune cells synthesize several inflammatory mediators (cytokines), including tumor necrosis factor-alpha (TNF- $\alpha$ ) and interleukins- 1 and -7 , which are important players in cartilage degradation [29]. Both IL-1 $\beta$ and TNF- $\alpha$ were shown to be increased, as well as the other cytokines (e.g., IL-8, IL-6, and leukotriene inhibitory factor), proteases, and prostaglandin E2 (PGE2) [30]. For example, IL-1 $\beta$ was found to be released from OA cartilage along with the inducible NOS (iNOS) [31]. PGE2 has also been reported to be spontaneously released by OA suffered cartilage [32], and leukotriene-B4 was elevated in the OA tissue synovial fluid [31]. In vitro and in vivo investigations have shown that overproduction of interleukin $1 \beta$ (IL-1 $\beta$ ) in OA is a key factor in degradation and disease progression [30]. These inflammatory mediators may trigger the production of many molecular factors such as MMPs, the enzymes which can degrade all constituents of the extracellular matrix [33]. Numerous MMPs are increased in the OA by either an elevation in their synthesis or reduced action of their suppressors [29]. MMP-1 is mainly produced by synovial cells that line the joints, and MMP-13 is a product of chondrocytes that reside in cartilage. Besides, the expression of other MMPs, including MMP-2, -3 and -9 , is raised in arthritis, and these enzymes degrade non-collagen matrix elements of the joints. The collagenases MMP-1 and MMP-13 show principal roles in OA since they are rate-limiting in the collagen degradation process [34]. Cartilage damage in OA is thought to be mediated by the MMPs, which are responsible for cartilage collagen breakdown [35]. Increased levels of stromelysin (MMP-3), collagenases (MMP-1, -8, and -13), along with the gelatinases (MMP-2 and -9), were reported in the OA chondrocytes or the articular cartilage surface $[29,36]$. Pro-inflammatory cytokines, such as IL-1, -17 , -18 , and TNF- $\alpha$ could promote the synthesis of MMPs, while reducing the MMP enzyme inhibitors, along with the extracellular matrix synthesis [29]. Also, a previous study has reported the positive effects of using diverse in vivo gene therapy strategies with IL-1Ra in OA [37]. It was revealed that licofelone, a drug that can block both the cyclooxygenase (COX) and 5-lipoxygenase (5-LOX) pathways, efficiently reduced the development of OA structural changes while simultaneously decreasing the synthesis of leukotriene-B4 (LTB4) and IL-1 $\beta$ by the OA synovium [38-40].

\section{Alternative Non-Surgical Treatment Approaches for OA}

The quest to find the active remedies that alleviate joint degradation, amend joint flexibility, and suppress joint pain has been compelling, and present cures for treating OA comprise acetaminophen and non-steroidal anti-inflammatory drugs (NSAIDs) [41]. In humans, arthritis has been suggested to affect a considerably relatively high ratio of the US adult population, and occur at an earlier age than formerly thought [42]. NSAIDs are the present-day gold-standard pharmaceutical cure for canines suffering OA, although NSAIDs may be the reason for gastrointestinal ulcerations as an adverse effect and are contraindicated when renal insufficiency or dehydration takes place [43]. Additional therapeutic alternatives include the corticosteroids, diacerein, along with hyaluronic acid. Certain nutraceuticals, for example, chondroitin, glucosamine, pentosane polysulfate, avocado/soybean unsaponifiables, milk protein, and green-lipped mussels, are used as add-on therapies [16,44]. Following the purpose of finding the exact remedy against $\mathrm{OA}$, our study group has recently suggested that, in collagen-induced arthritic rats, the arginine-silicate-inositol complex (ASI) is effective in lowering the inflammation markers $\beta$-catenin, COX-2, IL-6, MAPK, NF-kB, p38, TNF- $\alpha$, and WISP-1 levels in the joint tissue of the animals [45].

Progression of the arthritic disease leads to disability that is related to joint pain and dysfunction, and it is obvious that personalized and individualized prevention and treatment strategies are needed [26]. Because of the reason that collagen is the most ubiquitous ingredient of the articular cartilage solid phase [46], UC-II supplementation has been considered as an important treatment possibility to avoid articular cartilage damages over time while supporting the therapeutic process after the OA inception [17]. Some preventive and therapeutic agents can help to reduce or prevent the progression of OA (Table 1) [47]. 
Table 1. Main non-pharmacological and pharmaceutical preventative strategies in osteoarthritis treatments.

\begin{tabular}{cc}
\hline Non-Pharmacological and Preventative Strategies & Pharmaceutical Therapies \\
\hline Weight control & NSAIDs, corticosteroids, doxycycline, \\
\hline Knee misalignment and knee structure protection & MMP inhibitors \\
\hline Physical rehabilitation & IL-1 receptor antagonist (IL-1Ra) \\
management & Insulin growth factor-I (IGF-I) \\
\hline $\begin{array}{c}\text { Physical activity and muscle strengthening in } \\
\text { preventing osteoarthritis }\end{array}$ & Bone anti-resorptive agents \\
\hline Subchondral bone edema and bone resorption & Nutraceuticals: curcumin, EGCG, ASI \\
\hline $\begin{array}{c}\text { Partial meniscectomy and osteotomy } \\
\text { Tissue engineering }\end{array}$ & $\begin{array}{c}\text { Chondroitin sulfate, glucosamine sulfate, sodium } \\
\text { pentosan polysulfate, }\end{array}$ \\
\hline
\end{tabular}

These strategies include weight control and protection of the knee structure, knee misalignment, obesity and osteotomy, physical activity, muscle strengthening for the inhibition of OA, matrix metalloprotease inhibitors, and inhibition of cytokine. Therapeutic agents include glucosamine sulfate, chondroitin sulfate, UC-II, ASI, phytochemicals (e.g., curcumin, resveratrol), steroids, and hyaluronic acid $[17,47]$.

\section{UC-II and its Action Mechanism}

Collagens are extracellular matrix molecules used by the cells for structural integrity and a range of further functions [48]. Numerous hypotheses were suggested to clarify the precise mechanisms by which the collagen products enhance the articular cartilage health [17]. UC-II appears to exert joint-health benefits by oral tolerance, based on pre-clinical research. Oral tolerance is an immune process the body uses to distinguish between innocuous compounds (e.g., dietary proteins, intestinal bacteria) and potentially harmful foreign invaders. It takes place in the gut-associated lymphoid tissue (GALT). The GALT is mostly made up of mesenteric lymph nodes and patches of lymphoid tissue neighboring the small intestine (Peyer's patches) [49]. Peyer's patches take in and screen compounds from the gut lumen and, depending on the compound, switch the body's immune response on or off. When consumed, UC-II ${ }^{\circledR}$ undenatured type II collagen is believed to be taken up by the Peyer's patches, where it activates immune cells [50]. It transforms naive T-cells into T regulatory (Treg) cells that specifically target type II collagen. Treg cells then migrate through the circulation. When they recognize type II collagen in joint cartilage, Treg cells secrete anti-inflammatory mediators (cytokines), including the transforming growth factor-beta (TGF-beta), interleukin 4 (IL-4) and interleukin 10 (IL-10) [50,51]. This action helps reduce joint inflammation and promotes cartilage repair. Undenatured type II collagen contains active epitopes that are able to interact with Peyer's patches and induce oral tolerance. The key structural macromolecules of the cartilage tissue in the mammals are collagen and proteoglycans (aggrecan) [2,46]. Glucosamine, hyaluronic acid, and chondroitin sulfate are vital basic natural constituents of cartilage and synovial fluid. Denatured type II collagen, by contrast, lacks these essential structural components. Preclinical studies support oral tolerance as the mode of action of UC-II ${ }^{\circledR}$ undenatured type II collagen and confirm that the undenatured form of type II collagen is critical for joint-health benefits: In an animal model (mouse) of RA, only undenatured type II collagen protected against joint damage, an action attributed to oral tolerance [52]. In an animal model (rat) of RA, undenatured type II collagen provided symptom relief, an action attributed to oral tolerance and modulating inflammatory pathways [51]. In a cell study, Treg cells specific for type II collagen secreted anti-inflammatory cytokines, which play a chief role in the cells' ability to induce oral tolerance [53]. In a cell study with human chondrocytes (cells that make up cartilage), the 
anti-inflammatory action of IL-10 protects against damage from tumor necrosis factor-alpha (TNF- $\alpha$ ), a pro-inflammatory mediator elevated in osteoarthritis [54]. Clinically validated lab assays confirm active epitopes in UC-II ${ }^{\circledR}$ undenatured type II collagen resist digestion and retain the undenatured 3D-structure needed to interact with Peyer's patches and induce oral tolerance [49]. This process initiates anti-inflammatory and cartilage protective pathways that prevent the immune system from injuring its joint cartilage while promoting cartilage repair and regeneration. On the other hand, immunohistochemical staining and gene expression of proteins linked to cartilage metabolism, such as collagen type II and X, matrix metallopeptidase 13 (MMP-13), sex-determining region Y-box 9 (SOX9), and connective tissue growth factor (CCN2) expressions, were suggested to be performed in the rat models of OA [17]. A possible mechanism of action for UC-II activity is briefly summarized in Figure 2.

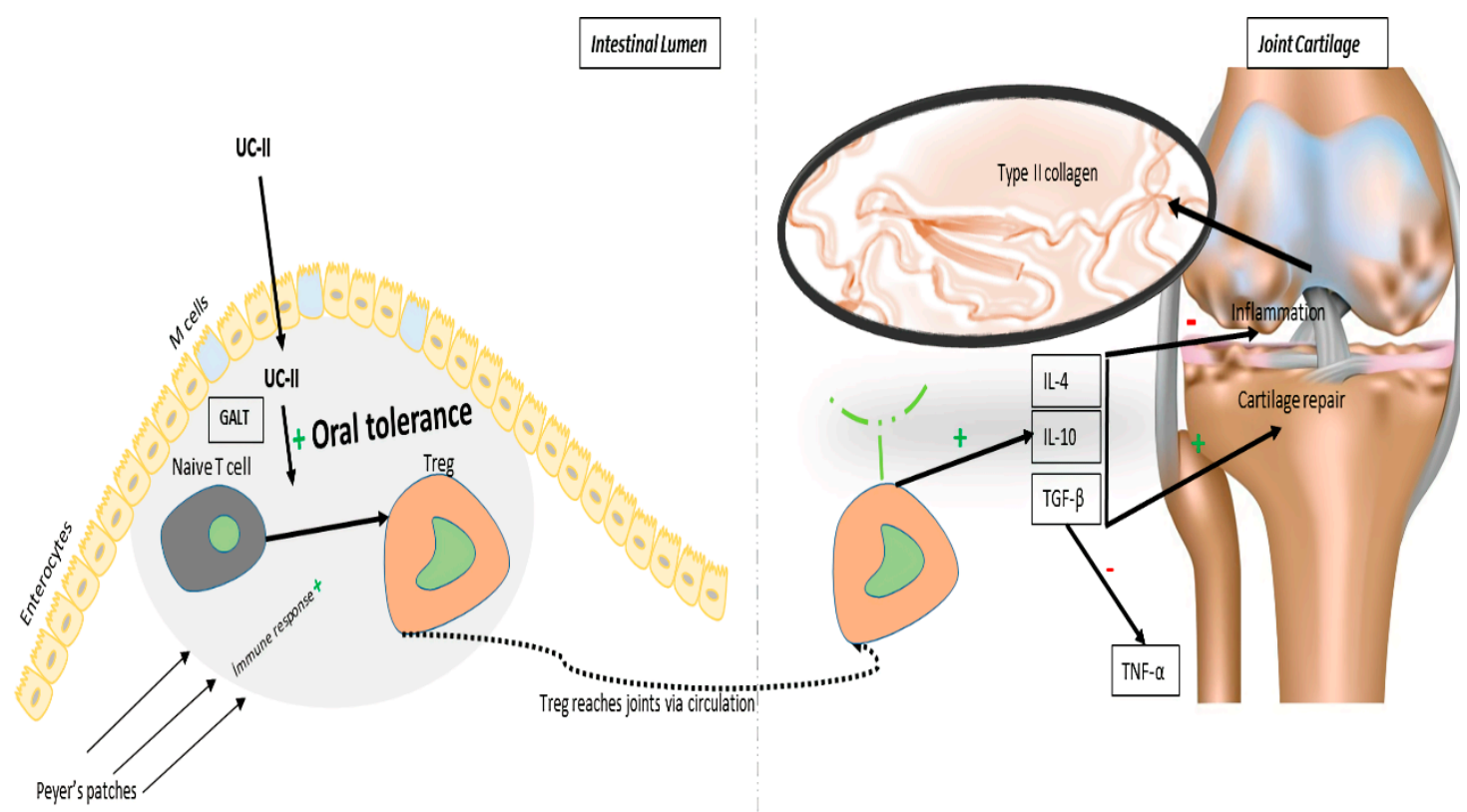

Figure 2. Schematic diagram of the proposed mode of action for type II collagen (UC-II) [17,55-60].

\section{Basic Add-on Therapies besides UC-II}

During the aging period production of glucosamine, the body's most abundant sugar and amino acid compound in mammals slows down together with the glycosaminoglycan chondroitin sulfate [13]. At present, glucosamine and chondroitin are the two most frequently used nutraceuticals that offer pharmaceutical, therapeutic, and health benefits to both human and animal arthritis patients [17]. Present medical remedies for arthritic dogs rely upon the drugs which relieve pain and regulate the inflammation to maintain daily activity [61]. Regular use of cyclooxygenase (COX) inhibitors (NSAIDs) is connected to several adverse effects, such as gastrointestinal (GI) hemorrhage and liver and kidney dysfunction [55]. In the recent past, two frequently used FDA-approved drugs (Rimadyl and Deramaxx), which are NSAIDs and elective inhibitors of COX-II, have been suggested as a reason for serious adverse effects and their safety is not evaluated in all the ages of dogs [62,63]. While paracetamol and NSAIDs are presently validated by clinical directives to treat OA [64], this emerging proof has challenged this endorsement and demonstrated the potential for adverse effects, such as cardiovascular side effects and NSAID-induced nephrotoxicity, besides GI bleeding. Glucosamine and hyaluronic acid are naturally synthesized by the body, but can also be provided via nutrition [65]. Glucosamine and chondroitin are generally recommended by veterinarians for the treatment of osteoarthritis in dogs despite the lack of compelling scientific evidence showing clinical benefit [43]. Animals-administered high intravenous concentrations of glucosamine could be especially sensitive to its diabetogenic effects via an increase of the hexosamine synthesis in the insulin-sensitive tissues, which could be a causative 
factor for the diabetes induction $[56,57,66]$. During euglycaemic-hyperinsulinaemic clamping, the glucosamine infusion in rodents, releasing plasma glucosamine concentrations of between 800 and $1200 \mu \mathrm{mol} / \mathrm{L}$, resulted in glucose intolerance and insulin insensitivity [58,59].

In several studies, no effect on fasting glucose levels or glucose tolerance observations were found in other species (rabbit and dog), and the lack of a diabetogenic effect in animal feeding studies was found consistent with the low bioavailability and lack of biological outcome on the glucose metabolism [57]. Supplementation of similar main ingredients may be valuable, particularly once there is a distressed balance amongst catabolic and anabolic processes, such as in OA. On the other hand, during the progression of $\mathrm{OA}$, the chondrocytes are no longer up to completely recompense the collagen type II fibers and proteoglycans loss, even at improved rates of the synthesis [22]. OA-induced animal models in dogs, rats, rabbits, and sheep have shown that hydroxycitric acid (HA) holds pleiotropic efficacy, including the anti-angiogenic, anti-fibrotic, anti-inflammatory, and anti-apoptotic effects. For instance, HA management of rats after the joint immobilization [60] or intra-articular IL-1 injection [67] were shown to protect against cartilage degeneration, seemingly because of both anti-inflammatory and anti-apoptotic effects. The main UC-II studies on humans and the animals, as well as the safety and efficacy studies, are summarized in Table 2. 
Table 2. Literature overview of UC-II practice in the human and animals for osteoarthritis (OA).

\begin{tabular}{|c|c|c|c|c|c|c|c|}
\hline No & Objective & Model & Dose and Duration & Core Findings & Conclusion & Safety & Ref. \\
\hline 1 & $\begin{array}{l}\text { Demonstrating the } \\
\text { UC-II ability, } \\
\text { whether it reduces } \\
\text { joint pain and } \\
\text { swelling in RA } \\
\text { subjects. }\end{array}$ & Human & $\begin{array}{l}\text { UC-II (10 mg/day) for } 42 \\
\text { days in five female } \\
\text { subjects ( } 58-78 \text { years) } \\
\text { suffering from severe } \\
\text { joint pain. }\end{array}$ & $\begin{array}{l}\text { Reduction of pain including } \\
\text { the stiffness was observed. }\end{array}$ & $\begin{array}{l}\text { UC-II found to serve as } \\
\text { a novel therapeutic tool } \\
\text { in joint inflammatory } \\
\text { conditions and } \\
\text { symptoms of both OA } \\
\text { and RA. }\end{array}$ & No Adverse events & [49] \\
\hline 2 & $\begin{array}{l}\text { Evaluating the } \\
\text { clinical } \\
\text { effectiveness and } \\
\text { safety of UC-II in } \\
\text { obese-arthritic } \\
\text { dogs. }\end{array}$ & Dogs & $\begin{array}{l}\text { Fifteen dogs in three } \\
\text { groups received either } \\
\text { UC-II }(0 \mathrm{mg} / \text { day }), \\
\text { ( } 1 \mathrm{mg} / \text { day }), \text { or } \\
\text { (10 mg/day) for } 90 \text { days, } \\
\text { plus } 30 \text { days } \\
\text { withdrawal. }\end{array}$ & $\begin{array}{l}\text { Both UC-II receiving groups } \\
\text { showed significant reductions } \\
\text { in overall pain as well as pain } \\
\text { during limb manipulation } \\
\text { and lameness after physical } \\
\text { exertion, also } 10 \text { mg showed } \\
\text { better improvement. } \\
\text { Additionally, no adverse } \\
\text { effects and no major } \\
\text { alterations were noted in the } \\
\text { serum chemistry, suggesting } \\
\text { that UC-II was well tolerated. }\end{array}$ & $\begin{array}{l}\text { Daily treatment of } \\
\text { arthritic dogs with } \\
\text { UC-II, shown to } \\
\text { ameliorate the signs and } \\
\text { symptoms of arthritis. } \\
\text { Relapse of pain was } \\
\text { observed during the } \\
\text { withdrawal period. }\end{array}$ & No Adverse events & [20] \\
\hline 3 & $\begin{array}{l}\text { Determining the } \\
\text { therapeutic } \\
\text { efficacy and safety } \\
\text { of glycosylated } \\
\text { active UC-II alone } \\
\text { or in combination } \\
\text { with hydroxycitric } \\
\text { acid (HA) and } \\
\text { chromium } \\
\text { niacinate }(\mathrm{CN}) \text {. }\end{array}$ & Dogs & $\begin{array}{l}\text { Five groups }(n=5) \text { of } 25 \\
\text { arthritic dogs received } \\
\text { daily treatments; group } \\
\text { I (Placebo control), } \\
\text { group II (10 mg active } \\
\text { UC-II), group III (1800 } \\
\text { mg HA), group IV }(1800 \\
\text { mg HA+100 lg CN), } \\
\text { and group V }(1800 \mathrm{mg} \\
\text { HA+100 lg CN+ } 10 \mathrm{mg} \\
\text { active UC-II). } \\
\text { The treatments were } \\
\text { given for } 120 \text { days and } \\
\text { followed up by a } \\
30 \text { days withdrawal } \\
\text { period. }\end{array}$ & $\begin{array}{l}\text { The dogs received the active } \\
\text { UC-II alone (group II) or in } \\
\text { combination (group V) for } \\
90 \text { days exhibited a noticeable } \\
\text { decrease in overall, pain upon } \\
\text { limb manipulation and } \\
\text { exercise-related lameness. } \\
\text { Maximum pain decrease was } \\
\text { seen in groups II and V after } \\
120 \text { days of treatment. A } \\
\text { relapse of pain was exhibited } \\
\text { in all the dogs after } 30 \text { days of } \\
\text { the withdrawal period. }\end{array}$ & $\begin{array}{l}\text { Active UC-II was found } \\
\text { to ameliorate the } \\
\text { arthritic dogs alone or in } \\
\text { combination with HA } \\
\text { and CN. } \\
\text { The supplements were } \\
\text { found to be well } \\
\text { tolerated and no adverse } \\
\text { effects were noted. }\end{array}$ & No Adverse events & [68] \\
\hline
\end{tabular}


Table 2. Cont

\begin{tabular}{|c|c|c|c|c|c|c|c|}
\hline No & Objective & Model & Dose and Duration & Core Findings & Conclusion & Safety & Ref. \\
\hline 4 & $\begin{array}{l}\text { Determining the } \\
\text { therapeutic } \\
\text { efficacy and safety } \\
\text { of glycosylated } \\
\text { active UC-II alone } \\
\text { or in combination } \\
\text { with } \\
\text { glucosamine-HCl } \\
\text { and chondroitin } \\
\text { sulfate. }\end{array}$ & Dogs & $\begin{array}{l}\text { Dogs were allocated } \\
\text { into four groups }(n=5), \\
\text { and orally treated daily } \\
\text { for } 120 \text { days. Treatments } \\
\text { were Group I (placebo } \\
\text { control), Group II (10 } \\
\text { mg UC-II), Group III } \\
\text { (2000 mg } \\
\text { glucosamine)+(1600 mg } \\
\text { chondroitin sulfate), } \\
\text { Group IV, UC-II (10 mg) } \\
+2000 \mathrm{mg} \text { glucosamine } \\
+1600 \text { mg chondroitin } \\
\text { sulfate, followed by a } \\
\text { 30-day withdrawal } \\
\text { period. }\end{array}$ & $\begin{array}{l}\text { UC-II alone received dogs } \\
\text { showed substantial } \\
\text { reductions in overall pain } \\
\text { within the first quarter of the } \\
\text { study. Maximum decreases in } \\
\text { pain were noted after } \\
120 \text { days of treatment. } \\
\text { Glucosamine and chondroitin } \\
\text { alleviated some pain, but in } \\
\text { combination with UC-II } \\
\text { (Group IV) significant } \\
\text { decreases were provided in } \\
\text { overall pain, pain upon limb } \\
\text { manipulation and } \\
\text { exercise-associated lameness. } \\
\text { Following the withdrawal of } \\
\text { supplements, all of the } \\
\text { animals experienced a relapse } \\
\text { of pain. }\end{array}$ & $\begin{array}{l}\text { UC-II alone or in } \\
\text { combination with } \\
\text { glucosamine and } \\
\text { chondroitin significantly } \\
\text { alleviated the arthritis } \\
\text { pain with daily } \\
\text { treatment to the arthritic } \\
\text { dogs, and these } \\
\text { supplements were } \\
\text { found to be well } \\
\text { tolerated without any } \\
\text { side effects. }\end{array}$ & No Adverse events & [69] \\
\hline 5 & $\begin{array}{l}\text { Evaluating the } \\
\text { efficiency of pain } \\
\text { lessening and } \\
\text { safety of UC-II in } \\
\text { arthritic horses. }\end{array}$ & Horses & $\begin{array}{c}\text { Six groups of arthritic } \\
\text { horses }(n=5-6) . \\
\text { G. I (placebo control), } \\
\text { G. II (UC-II } 20 \mathrm{mg} / \text { day), } \\
\text { G. III (UC-II } 40 \mathrm{mg} / \text { day), } \\
\text { G. IV (UC-II } 80 \mathrm{mg} / \text { day), } \\
\text { G. V (UC-II } 120 \mathrm{mg} / \text { day), } \\
\text { G. VI (UC-II } \\
160 \mathrm{mg} / \text { day). A period } \\
\text { of } 150 \text { days. }\end{array}$ & $\begin{array}{l}\text { Groups IV, V, and VI of the } \\
\text { horses exhibited significant } \\
\text { improvements in the arthritic } \\
\text { signs. Reduction in overall } \\
\text { pain was at } 79 \% \text {, in pain upon } \\
\text { limb manipulation was at } \\
71 \% \text {, and in pain, after } \\
\text { physical exertion was at } 68 \% \text {. } \\
\text { Horses receiving a higher } \\
\text { dose of } 120 \text { and } 160 \text { mg of } \\
\text { UC-II/day showed very little } \\
\text { or no signs of arthritis. }\end{array}$ & $\begin{array}{l}\text { UC-II at higher doses } \\
\text { (80-160 mg/day) in the } \\
\text { horses ameliorated the } \\
\text { signs and symptoms of } \\
\text { arthritis, which was also } \\
\text { well-tolerated. }\end{array}$ & No Adverse events & [70] \\
\hline
\end{tabular}


Table 2. Cont.

\begin{tabular}{|c|c|c|c|c|c|c|c|}
\hline No & Objective & Model & Dose and Duration & Core Findings & Conclusion & Safety & Ref. \\
\hline 6 & $\begin{array}{l}\text { Assessing the } \\
\text { safety and efficacy } \\
\text { of UC-II as } \\
\text { compared to a } \\
\text { combination of } \\
\text { glucosamine and } \\
\text { chondroitin (G + } \\
\text { C) in the treatment } \\
\text { of OA of the knee. }\end{array}$ & Human & $\begin{array}{l}\text { A total of } 52 \text { subjects, } \\
\text { half of them }(n=26) \\
\text { took a daily dose of } 40 \\
\text { mg UC-II containing } 10 \\
\text { mg of bioactive } \\
\text { undenatured type II } \\
\text { collagen via } 2 \text { capsules. } \\
\text { Another half of the } \\
\text { subjects ( } n=26) \text { took } \\
\text { a daily dose of } 1500 \mathrm{mg} \\
\text { glucosamine and } 1200 \\
\text { mg chondroitin via } 4 \\
\text { capsules. }\end{array}$ & $\begin{array}{l}\text { UC-II treatment found to be more } \\
\text { effective when decreasing all the } \\
\text { assessments from the baseline at } \\
90 \text { days. In the } G+C \text { treatment } \\
\text { group, this effect was not observed. } \\
\text { Specifically, although both } \\
\text { treatments reduced the Western } \\
\text { Ontario McMaster Osteoarthritis } \\
\text { Index (WOMAC) score was two } \\
\text { folds better reduced by UC-II, than } \\
\text { the G + C treated group after } \\
90 \text { days. }\end{array}$ & $\begin{array}{l}\text { UC-II treatment to the } \\
\text { subjects exhibited } \\
\text { noteworthy } \\
\text { enhancement in daily } \\
\text { activities, which } \\
\text { suggested } \\
\text { improvements for their } \\
\text { life quality. }\end{array}$ & No Adverse events & [71] \\
\hline 7 & $\begin{array}{l}\text { Evaluating the } \\
\text { arthritic pain } \\
\text { reduction in the } \\
\text { horses and } \\
\text { comparison of its } \\
\text { efficacy with the } \\
\text { glucosamine and } \\
\text { chondroitin }\end{array}$ & Horses & $\begin{array}{c}\text { Five groups of moderate } \\
\text { severity arthritic horses } \\
(n=5-7) ; \text { Group-I } \\
\text { placebo, Group-II } 320 \\
\text { mg UC-II, Group-III } 480 \\
\text { mg UC-II, Group-IV } 640 \\
\text { mg UC-II, Group-V } \\
\text { glucosamine + } \\
\text { chondroitin }\end{array}$ & $\begin{array}{l}\text { The placebo group showed no } \\
\text { change in arthritic conditions, } \\
\text { whereas those receiving } 320,480, \\
\text { and } 640 \text { mg UC-II showed } \\
\text { significant reductions in arthritic } \\
\text { pain. }\end{array}$ & $\begin{array}{l}\text { All supplements were } \\
\text { tolerated well. } \\
\text { Generally, results from } \\
\text { this study demonstrated } \\
\text { UC-II to be significantly } \\
\text { more effective than the } \\
\text { glucosamine and } \\
\text { chondroitin } \\
\text { supplements in arthritic } \\
\text { horses. }\end{array}$ & No Adverse events & [72] \\
\hline 8 & $\begin{array}{l}\text { Assessing the } \\
\text { safety and } \\
\text { therapeutic } \\
\text { effectiveness of } \\
\text { UC-II in arthritic } \\
\text { dogs }\end{array}$ & Dogs & $\begin{array}{l}\text { Dogs were daily treated } \\
\text { with either placebo or } \\
\text { UC-II (10 mg active } \\
\text { UC-II) for } 120 \text { days. }\end{array}$ & $\begin{array}{l}\text { Substantial decreases }(77 \%) \text { were } \\
\text { found in the overall pain of the } \\
\text { dogs after the study period, } \\
\text { inconsistent with pain reduction } \\
(83 \%) \text { after limb manipulation and } \\
\text { pain reduction after physical } \\
\text { exercise }(84 \%) \text {. Subchronic toxicity } \\
\text { and primary dermal and eye } \\
\text { irritation studies showed no } \\
\text { adverse effects and UC-II did not } \\
\text { induce mutagenic effects. }\end{array}$ & $\begin{array}{l}\text { Study results } \\
\text { demonstrated that UC-II } \\
\text { significantly reduces } \\
\text { arthritic pain and is safe. }\end{array}$ & No Adverse events & [73] \\
\hline
\end{tabular}


Table 2. Cont

\begin{tabular}{|c|c|c|c|c|c|c|c|}
\hline No & Objective & Model & Dose and Duration & Core Findings & Conclusion & Safety & Ref. \\
\hline 9 & $\begin{array}{l}\text { Determining the } \\
\text { tolerability and } \\
\text { safety of the } \\
\text { therapeutic } \\
\text { efficacy of type II } \\
\text { collagen (UC-II) } \\
\text { alone or in } \\
\text { combination with } \\
\text { glucosamine } \\
\text { hydrochloride } \\
\text { (GLU) and } \\
\text { chondroitin } \\
\text { sulphate (CHO). }\end{array}$ & Dogs & $\begin{array}{c}4 \text { groups }(n=7-10), \\
\text { were treated daily with; } \\
\text { placebo (Group-I), } \\
10 \text { mg active UC-II } \\
\text { (Group-II), } \\
2000 \text { mg GLU + 1600 mg } \\
\text { CHO (Group-III), } \\
\text { and UC-II + GLU + } \\
\text { CHO (Group-IV), for } \\
150 \text { days. }\end{array}$ & $\begin{array}{l}\text { A significant reduction in } \\
\text { pain was noted in Groups II, } \\
\text { III, and IV of dogs. Significant } \\
\text { increases in peak vertical } \\
\text { force (N/kg body wt) and } \\
\text { impulse area (N/kg body wt), } \\
\text { indicative of a decrease in } \\
\text { arthritis-associated pain, were } \\
\text { observed in Group-II (10 mg } \\
\text { active UC-II) dogs only. None } \\
\text { of the dogs in any group } \\
\text { showed changes in physical, } \\
\text { hepatic, or renal functions. }\end{array}$ & $\begin{array}{l}\text { When moderately } \\
\text { arthritic dogs treated } \\
\text { with UC-II (10 mg), } \\
\text { a marked reduction in } \\
\text { arthritic pain with } \\
\text { maximum improvement } \\
\text { occurred by day } 150 .\end{array}$ & No Adverse events & [74] \\
\hline 10 & $\begin{array}{l}\text { Assessing the } \\
\text { efficacy and } \\
\text { tolerability of } \\
\text { UC-II in the } \\
\text { moderation of the } \\
\text { joint function/pain } \\
\text { due to strenuous } \\
\text { exercise in } \\
\text { healthy subjects. }\end{array}$ & Human & $\begin{array}{l}55 \text { subjects who } \\
\text { reported knee joint pain } \\
\text { after joining in a } \\
\text { standardized step mill } \\
\text { performance test were } \\
\text { randomized to take } \\
\text { placebo }(n=28) \text { or the } \\
\text { UC-II }(40 \text { mg daily, } \\
n=27) \text { product for } \\
120 \text { days. }\end{array}$ & $\begin{array}{l}\text { Subjects in the UC-II group } \\
\text { showed significant } \\
\text { improvements in average } \\
\text { knee extension compared to } \\
\text { placebo and to baseline. } \\
\text { The UC-II cohort also } \\
\text { revealed a significant change } \\
\text { in average knee extension at } \\
\text { day } 90 \text { versus baseline. }\end{array}$ & $\begin{array}{l}\text { Daily supplementation } \\
\text { with } 40 \text { mg of UC-II } \\
\text { found to be well } \\
\text { tolerated and led to } \\
\text { improved knee joint } \\
\text { extension. UC-II also } \\
\text { showed the potential of } \\
\text { increasing the period of } \\
\text { pain-free strenuous } \\
\text { exertion and lessen the } \\
\text { joint pain from that. }\end{array}$ & No Adverse events & [75] \\
\hline 11 & $\begin{array}{l}\text { Evaluating the } \\
\text { efficacy and safety } \\
\text { of } 150 \text { mg of } \\
\text { n-enriched } \\
\text { THIAA }+10 \text { mg of } \\
\text { UC-II in } \\
\text { each tablet }\end{array}$ & Human & $\begin{array}{c}\text { Participants took } 2 \\
\text { tablets of nTHIAA }+ \\
\text { UC-II } 2 \times / \text { d with meals } \\
\text { for } 12 \text { weeks. }\end{array}$ & $\begin{array}{l}\text { All participants reported } \\
\text { significant improvements in } \\
\text { pain. The studied supplement } \\
\text { was well tolerated, and no } \\
\text { serious side effects occurred. }\end{array}$ & $\begin{array}{l}\text { nTHIAA and UC-II } \\
\text { were found to be safe } \\
\text { and efficacious in } \\
\text { participants having } \\
\text { chronic joint pain. }\end{array}$ & No Adverse events & {$[50]$} \\
\hline
\end{tabular}


Table 2. Cont

\begin{tabular}{|c|c|c|c|c|c|c|c|}
\hline No & Objective & Model & Dose and Duration & Core Findings & Conclusion & Safety & Ref. \\
\hline 12 & $\begin{array}{l}\text { Evaluating the } \\
\text { efficacy and safety } \\
\text { of UC-II for knee } \\
\text { OA pain and } \\
\text { affiliated } \\
\text { symptoms } \\
\text { compared to } \\
\text { glucosamine } \\
\text { hydrochloride and } \\
\text { chondroitin } \\
\text { sulfate (GC). }\end{array}$ & Human & $\begin{array}{l}191 \text { volunteers were } \\
\text { randomized into three } \\
\text { groups receiving a daily } \\
\text { dose of UC-II ( } 40 \mathrm{mg}), \\
\text { GC (1500 mg G and } 1200 \\
\text { mg C), or placebo for } \\
180 \text { days. }\end{array}$ & $\begin{array}{l}\text { UC-II group demonstrated a } \\
\text { significant reduction in } \\
\text { overall WOMAC score } \\
\text { compared to placebo and GC. } \\
\text { Supplementation with UC-II } \\
\text { also resulted in significant } \\
\text { changes for all three WOMAC } \\
\text { subscales. Safety outcomes } \\
\text { did not differ among the } \\
\text { groups. }\end{array}$ & $\begin{array}{l}\text { UC-II improved knee } \\
\text { joint symptoms in knee } \\
\text { OA subjects and was } \\
\text { well-tolerated. }\end{array}$ & No Adverse events & {$[76]$} \\
\hline 13 & $\begin{array}{l}\text { Assessing the } \\
\text { UC-II to } \\
\text { prevention against } \\
\text { the excessive } \\
\text { articular cartilage } \\
\text { deterioration in a } \\
\text { partial medial } \\
\text { meniscectomy tear } \\
\text { (PMMT) surgery } \\
\text { performed rat } \\
\text { model of OA. }\end{array}$ & Rats & $\begin{array}{l}20 \text { male rats were used } \\
\text { in this study. } 10 \text { rats } \\
\text { received the vehicle and } \\
\text { another } 10 \text { rats received } \\
\text { an oral daily dose of } \\
\text { UC-II at } 0.66 \mathrm{mg} / \mathrm{kg} \text { for } \\
8 \text { weeks. }\end{array}$ & $\begin{array}{l}\text { PMMT surgery created a } \\
\text { moderate OA at the medial } \\
\text { tibia plateau. Immediate } \\
\text { treatment with the UC-II } \\
\text { protected the weight-bearing } \\
\text { capacity of the injured leg, } \\
\text { preserved the integrity of the } \\
\text { cancellous bone at tibial } \\
\text { metaphysis and limited the } \\
\text { excessive osteophyte } \\
\text { formation and deterioration } \\
\text { of articular cartilage. }\end{array}$ & $\begin{array}{l}\text { This study demonstrates } \\
\text { that a clinically relevant } \\
\text { daily dose of UC-II } \\
\text { when applied } \\
\text { immediately after an } \\
\text { injury can improve the } \\
\text { mechanical function of } \\
\text { the injured knee and } \\
\text { prevent excessive } \\
\text { deterioration of articular } \\
\text { cartilage. }\end{array}$ & No Adverse events & [17] \\
\hline 14 & $\begin{array}{l}\text { The palatability } \\
\text { and tolerability of } \\
\text { UC-II was studied }\end{array}$ & Cats & $\begin{array}{l}33 \text { European Shorthair } \\
\text { cats between the ages of } \\
24 \text { to } 72 \text { months were } \\
\text { given one chewable } \\
\text { tablet containing } 10 \mathrm{mg} \\
\text { of UC-II, daily for } \\
40 \text { days. }\end{array}$ & $\begin{array}{l}\text { No remarkable findings on } \\
\text { physical examination before } \\
\text { or after the study and no } \\
\text { appreciable changes in body } \\
\text { weight were noted. } \\
\text { The consumption level rose } \\
\text { from } 58 \% \text { on day } 0 \text { to } 73 \% \text { on } \\
\text { day } 40 \text {. After an initial } \\
\text { acquaintance period of } \\
2-3 \text { weeks, the level of } \\
\text { consumption within } 5 \text { mins } \\
\text { rose to over } 70 \% \text {. }\end{array}$ & $\begin{array}{l}10 \text { mg of UC-II found to } \\
\text { be very palatable in the } \\
\text { cats studied and was } \\
\text { well-tolerated based on } \\
\text { physical examination. }\end{array}$ & No Adverse events & [77] \\
\hline
\end{tabular}


Table 2. Cont

\begin{tabular}{|c|c|c|c|c|c|c|c|}
\hline No & Objective & Model & Dose and Duration & Core Findings & Conclusion & Safety & Ref. \\
\hline 15 & $\begin{array}{l}\text { Analyzing the } \\
\text { efficacy of UC-II } \\
\text { alone or combined } \\
\text { with cimicoxib, for } \\
\text { OA treatment. }\end{array}$ & Dogs & $\begin{array}{l}45 \text { dogs: } 13 \text { cimicoxib, } \\
20 \text { UC-II, and } 12 \\
\text { cimicoxib + UC-II. } \\
\text { Cimicoxib ( } 2 \mathrm{mg} / \mathrm{kg} \text { die) } \\
\text { and UC-II tablet /day. } \\
\text { Study lasted for } 30 \text { days. }\end{array}$ & $\begin{array}{l}\text { There was a significant } \\
\text { reduction in LOAD scores } \\
\text { after the study. Treatment of } \\
\text { similar magnitude among the } \\
\text { three groups (CIMI }=31.8 \%, p \\
<0.001 \text {; UC-II }=32.7 \%, p= \\
0.013 ; \mathrm{CIM}+\mathrm{UC}-\mathrm{II}=31.7 \%, p \\
=0.009) \text {. Preliminary results } \\
\text { of the study show similar } \\
\text { effectiveness of the } 3 \\
\text { treatments in reducing the } \\
\text { degree of impairment of } \\
\text { mobility in dogs with OA. }\end{array}$ & $\begin{array}{l}\text { UC-II, while not } \\
\text { showing a synergistic } \\
\text { effect with cimicoxib, } \\
\text { provided a comparable } \\
\text { clinical efficacy to the } \\
\text { NSAIDs itself. }\end{array}$ & No Adverse events & [78] \\
\hline 16 & $\begin{array}{l}\text { This study aimed } \\
\text { to evaluate the } \\
\text { effects of UC-II as } \\
\text { compared to } \\
\text { robenacoxib in OA } \\
\text { suffering dogs. }\end{array}$ & Dogs & $\begin{array}{l}60 \text { client-owned dogs } \\
\text { were randomized in the } \\
\mathrm{R} \text { group ( } n=30, \\
\text { robenacoxib } \\
1 \mathrm{mg} / \mathrm{kg} / \text { day for } 30 \text { days) } \\
\text { and in the UC-II group } \\
(n=30, \text { UC-II } 1 \\
\text { tablet/day for } 30 \text { days). }\end{array}$ & $\begin{array}{l}\text { Based on the data obtained } \\
\text { from the study, a significant } \\
\text { reduction in LOAD and } \\
\text { MOBILITY scores was } \\
\text { recorded between T0 and T30 } \\
\text { with a similar magnitude } \\
\text { among the two groups }(\mathrm{R}= \\
31.5 \%, p<0.001 ; \mathrm{UC}-\mathrm{II}= \\
32.7 \%, p=0.013) .\end{array}$ & $\begin{array}{l}\text { This study showed that } \\
\text { UC-II and robenacoxib } \\
\text { were able to similarly } \\
\text { improve mobility of } \\
\text { dogs affected by OA. }\end{array}$ & No Adverse events & [79] \\
\hline 17 & $\begin{array}{l}\text { Assessing the } \\
\text { safety and } \\
\text { effectiveness of } \\
\text { un-denatured type } \\
2 \text { collagen in the } \\
\text { management of } \\
\text { OA performed in } \\
\text { patients by } 18 \\
\text { orthopaedicians }\end{array}$ & Human & $\begin{array}{c}291 \text { patients were } \\
\text { enrolled and } \\
\text { followed-up at day } 30 \\
\text { (visit 2), day } 60 \text { (visit 3), } \\
\text { and day } 90 \text { (visit 4). } \\
\text { Efficacy was assessed by } \\
\text { and WOMAC and } \\
\text { Visual Analogue scale } \\
\text { (VAS) on each visit. }\end{array}$ & $\begin{array}{l}226 \text { of } 291 \text { patients completed } \\
\text { the } 90 \text { days study. Treatment } \\
\text { with UC-II was related to a } \\
\text { significant reduction in } \\
\text { WOMAC and VAS scores. }\end{array}$ & $\begin{array}{l}\text { UC-II was safe and } \\
\text { efficacious in Indian } \\
\text { patients having OA, } \\
\text { which could be } \\
\text { considered in the early } \\
\text { management of OA. }\end{array}$ & No Adverse events & [80] \\
\hline
\end{tabular}


Table 2. Cont

\begin{tabular}{|c|c|c|c|c|c|c|c|}
\hline No & Objective & Model & Dose and Duration & Core Findings & Conclusion & Safety & Ref. \\
\hline 18 & $\begin{array}{l}\text { The purpose of the } \\
\text { present study was } \\
\text { to asses the } \\
\text { outcome of } \\
\text { collagen type II IN } \\
\text { osteoarthritis of } \\
\text { the knee joint. }\end{array}$ & Human & $\begin{array}{l}100 \text { randomly selected } \\
\text { patients that received a } \\
\text { daily dose of UC-II ( } 40 \\
\mathrm{mg} \text { ) for } 120 \text { days. }\end{array}$ & $\begin{array}{l}\text { UC-II showed a significant } \\
\text { reduction in the overall } \\
\text { WOMAC score, LFI, and VAS } \\
\text { scores in } 120 \text { days of } \\
\text { observation. The UC-II led to } \\
\text { significant changes in the } \\
\text { three WOMAC subscales: } \\
\text { pain } p=0.0005 \text {; stiffness } \\
p=0.004 \text {; physical function } \\
p=0.004 \text {. }\end{array}$ & $\begin{array}{l}\text { UC-II improved the } \\
\text { knee joint function in } \\
\text { knee OA. }\end{array}$ & No Adverse events & [81] \\
\hline
\end{tabular}




\section{OA Prevalence in Dogs}

OA is the most widespread form of the arthritis type in humans and dogs, which refers to chronic joint inflammation that is caused by the cartilage deterioration. Nearly 25 percent of the 77.2 million pet dogs in the USA are diagnosed with arthritis. Dog OA is generally thought to show a similarity to human OA in terms of anatomical similarity, disease heterogeneity, and progress as well [82]. For instance, differences in articular cartilage proteoglycans occurring in slowly progressive spontaneous dog OA are strictly matched but different from those occurring in human OA. In dogs, $\mathrm{OA}$ is more common than RA, and pain is the leading observation. In nearly all forms of arthritis, a loss of bone or cartilage leads to a modification in the shape of joints [83]. Eventually, proteoglycan and collagen fragments are released into the synovial fluid in this stage [13]. In the adult dog, proteoglycan turnover is quicker than estimated collagen turnover, and distinct articular cartilage proteoglycan loss is permanent, which results in joint deterioration [84]. OA is typically defined as a multifactorial illness with a resilient hereditary part and can worsen by lifestyle choices to each dog specifically, which comprise diet and exercise levels [85]. In dogs, OA is mostly defined as secondary, whereby a previous major joint aberration, including the cruciate ligament rupture or patellar luxation, is supposed to stimulate the following OA growth [86]. It is not clear what percentage of dogs grow OA secondary to these or other specific predisposing situations [87].

It is mostly later in a dog's life that OA turns out to be a more important problem as it has been suggested that more than $50 \%$ of diagnosed dogs are aged at $8-13$ years, and thus the condition is characteristically diagnosed when mobility is significantly affected [88]. The duration that dogs are affected by OA has not been well informed in the literature due to difficulty in identifying the exact onset of the disorder and limited accessibility of long-term cohort clinical data on confirmed cases. Even though the OA may initiate at any age, it may not be clinically diagnosed until it reaches an advanced stage with clear external clinical symptoms [89]. Moreover, even though joint deterioration may already be existing when the originating cause is identified, at this point, it may not have been recorded or encoded as OA in clinical notes yet. Long term studies have found that OA can affect a considerable amount of lifespan in some affected dogs [90].

Predictions from North America have reported that the age-specific OA prevalence ranged from 20 percent in dogs older than 1 year to 80 percent in dogs older than 8 years, depending on radiographic and clinical data [91], whereas dog OA prevalence in the reported literature shows contradictory values. In the UK dog population, estimations have ranged from 6.6 percent based on primary-care data [9] to 20 percent based on referral data [89]. In the UK, among 16,437 identified candidate OA cases, 6104 of them were checked manually and 4196 of the dogs (69\%) were confirmed as cases. The estimated yearly period prevalence of OA diagnosis in dogs under primary veterinary care in the UK during the year 2013 was found to be 2.5 percent. The most often affected breed prevalence was calculated as well and the most prevalent breeds were the large dog breeds, especially golden retrievers $(7.7 \%)$, labrador retrievers $(6.1 \%)$, rottweilers (5.4\%), and german shepherds (4.9\%) [12]. Almost $20 \%$ of the domestic canine population spontaneously develop OA, which is equal to nearly 15 million dogs in the USA alone. Growing evidence showed that the OA results from companion dogs reliably help to predict the drug/supplement efficiency in humans [7]. Parallel results have been seen in human studies, with many compounds of the studies undertaken in dogs having chronic pain conditions being the same as in humans [92,93]. In dogs, chondroitin sulfate, glucosamine hydrochloride, and sulfate have been considered for their anti-OA properties, which were reported to induce glycosaminoglycan formation and aggrecan production [16]. However, besides MMP-13 being a degrading collagen, it was also found to degrade the proteoglycan molecule aggrecan, therefore playing a twin role in the matrix destruction while its selective inhibition seems to have promising therapeutic approaches [34]. These supplements were reported to exert anti-catabolic and anti-inflammatory effects via the suppression of nuclear factor КB (NF-kB) binding activity [94]. 
UC-II Usage in Dogs

Many studies have shown that UC-II improves joint mobility, flexibility, and comfort by preventing the immune system from attacking and damaging the articular cartilage [95-97]. In a study to assess the clinical effectiveness and safety of UC-II, obese-arthritic dogs receiving UC-II with 1 or $10 \mathrm{mg}$ of UC-II/day for 90 days demonstrated reductions in the levels of overall pain, lameness, and pain during limb manipulation after the physical exercise, with $10 \mathrm{mg}$ showing a greater improvement. In the same study, no adverse effects were observed in both UC-II doses, and no vital changes in serum biochemical parameters indicated that the toleration of UC-II was good. Moreover, dogs receiving UC-II for 90 days showed an increase in physical activity levels. After the withdrawal of UC-II over 30 days, all dogs experienced a general relapse, pain during exercise-related lameness, and limb manipulation [69]. In another study, the researchers tried to assess the therapeutic effectiveness and safety of glycosylated UC-II alone or in combination with glucosamine- $\mathrm{HCl}$ and chondroitin sulfate in 20 arthritic dogs, which were allocated into 4 groups and orally treated for 120 days. Briefly, $10 \mathrm{mg}$ of UC-II was found to be superior to glucosamine and chondroitin, while the study suggested that regular treatment of arthritic dogs using UC-II alone or in combination with glucosamine and chondroitin ameliorated the signs and symptoms of arthritis considerably better than both glucosamine and chondroitin. Moreover, maximum decreases in pain were noted following the 120 days of treatment (overall pain decrease was found as $62 \%$; pain reduction upon limb manipulation was detected as $91 \%$, and the decrease in exercise-associated lameness was 78\%) [20]. In another research, Gupta et al. [74] conducted a study to assess the therapeutic effectiveness of UC-II alone or in combination with glucosamine hydrochloride and chondroitin sulfate on client-owned moderate arthritic dogs and to determine their tolerance and safety. For this purpose, the dogs were daily treated with placebo, $10 \mathrm{mg}$ active UC-II, $2000 \mathrm{mg}$ glucosamine hydrochloride $+1600 \mathrm{mg}$ chondroitin sulfate, and or in UC-II combined with glucosamine-hydrochloride and chondroitin-sulfate for 150 days. A significant decrease in pain was noted in the treated dogs. However, significant rises in the quantitative ground force plate (GFP) parameters (peak perpendicular force and impulse area), which is indicative of an important reduction in discomfort with arthritis, were observed only in dogs treated with UC-II. None of the dogs in the groups showed changes in physical status or liver and kidney functions. This means that active UC-II supplementation alone (10 mg/day for 150 days) was well tolerated and increased the well-being significantly in moderately arthritic dogs [74]. Another water-soluble UC-II form also exhibited similar noteworthy efficiency in relieving pain and inflammation in collagen-induced arthritis in mice, as well as moderately arthritic dogs after 150 days of supplementation with $10 \mathrm{mg}$ of dosage when compared to control dogs [98,99]. In a clinical, randomized, controlled, and prospective study [79], 60 client-owned dogs were randomly allocated to the $\mathrm{R}$ group $(n=30$, robenacoxib $1 \mathrm{mg} / \mathrm{kg} / \mathrm{day})$ and the UC-II group (UC-II 1 tablet $(40 \mathrm{mg}$ )/day) for a 30 days study. Based on the data obtained from the study, there was a significant reduction in the Liverpool osteoarthritis in dogs (LOAD) and mobility scores among $\mathrm{T} 0$ and $\mathrm{T} 30$ of similar size between the two groups ( $\mathrm{R}=31.5 \%$, UC-II $=32.7 \%$ ). The researchers indicated that robenacoxib and UC-II similarly improved mobility of the dogs affected by OA.

\section{OA Prevalence in Horses}

Spontaneous joint disease is a common clinical problem in the horse. Among joint diseases, the prevalence of osteoarthritis is high, and osteoarthritis is a frequent cause of morbidity as a result of pain that is typically involved with this disease [100]. The prevalence of OA differs depending on the disease definition and reported target population. In a cross-sectional survey of horses in the UK, it was reported at $13.9 \%$ [101]. Also, the prevalence of OA found to be $50 \%$ greater than in the horses older than 15 years and up to $80 \%-90 \%$ in horses over 30 years [102]. In horses, OA compromises the equine industry, not only because of the treatment costs but also as a result of reduced athletic performance. Numerous epidemiological studies have suggested the prevalence of OA disease, including reports of its great incidence (more than $80 \%$ ) even in Mangalarga Marchador foals aged between 12 to 36 months [103], which demonstrates that this disorder mostly affects adult 
and elderly horses but can also evolve in young horses and foals as well [104,105]. This situation has been stated to be because of the premature beginning of horse exercise throughout the early periods of musculoskeletal system development or because of the extreme and/or lengthy mechanical loads on undeveloped articular cartilage, by periarticular tissues incapably developed to support strong loads in many cases [106].

The prevalence and severity of metacarpophalangeal joint osteoarthritis were studied using measurable macroscopic evaluations of joints from 50 horses of different ages. They have found that one-third of horses with 2- and 3- year olds had partial or thickness lesions in the cartilage, along with the OA. Additionally, the severity of the disorder was augmented until horses become 6 years of age. In the aforementioned study, it was required to study the factors that might make 2-year-old horses susceptible to early joint affection, comprising hereditary, nutritious, and management factors as well [106]. In horses, the competing incapability is due mainly to OA, and the most common reason for euthanasia is lameness due to joint problems [107].

\section{UC-II Usage in Horses}

In a horse study for assessing the safety and pain reduction activity of the UC-II, six groups of arthritic animals $(n=5-6)$ were tested. The researchers designed the groups as Group I: placebo, Group II: 20 mg/day, Group III: 40 mg/day, Group IV: 80 mg/day, Group V: 120 mg/day, and Group VI: $160 \mathrm{mg} /$ day of UC-II, for 150 days. After the study, while placebo OA horses exhibited no changes in arthritic conditions, Groups II and III showed slight improvement. The horses that received 80, 120, and $160 \mathrm{mg}$ UC-II/day revealed significant and marked improvements in the arthritic signs and were running by the end of the study [70]. In another study, horses $(n=5-6)$ received UC-II $(320,480$, or $640 \mathrm{mg}$ ) twice daily for the first month and once daily thereafter. A significant decrease in arthritic pain was reported in horses received all dosage of UC-II. The higher daily doses of UC-II (480 and $640 \mathrm{mg}$ ) delivered equal welfares, representing $480 \mathrm{mg} /$ day was ideal [72]. At this dose, the overall discomfort was decreased from $100 \%$ to $12 \%$ and the discomfort on limb manipulation was decreased from $100 \%$ to $22 \%$. In the same study, glucosamine- and chondroitin-treated groups similarly revealed an important reduction in pain compared with pretreated values, whereas the efficacy was not as much of when compared with that observed with UC-II. Indeed, UC-II at 480 or $640 \mathrm{mg}$ doses were more effective than glucosamine and chondroitin in arthritic horses [72].

\section{OA Prevalence in Cats}

Cats, in contrast to most dogs, can endure severe orthopedic ailments because of their small size and natural agility. Variations to OA-affected joints in cats are usually subtle. Reduced range of joint motion is generally rare in cats in comparison to dogs [108]; however, it has been reported to be more common than it is expected [109]. The huge majority of the feline OA cases are primary OA that seen in older cats with no apparent originating factor, from time to time referred to as age-related cartilage degeneration. Secondary OA in cats can be caused by several predisposing conditions such as congenital abnormality or joint irregularity and often seem after traumatic joint damage. While the prevalence of feline osteoarthritis (OA) varies, it is possibly due to dissimilar studies that have involved varying age groups of cats [110]. The primary standard for diagnosing radiographic OA is the occurrence of osteophytes; however, radiographically typical joints can also be affected by articular cartilage pathology; thus, radiographic studies are possible to undervalue the OA prevalence [111]. Nevertheless, while the prevalence of feline OA varies between publications and is likely to be biased for numerous reasons [112-114], more like the recent prospective, cross-sectional studies are possible to be less biased [110,115]. In cats older than 12 years of age, a $26 \%$ radiographic prevalence of appendicular OA and a $90 \%$ prevalence of total types of degenerative joint disease were found [114]. In another study, the appendicular joints of 100 cats, no specific inclusion criteria were found, and the cats were aged above 6 years, while all the cases referred to the university clinic, mostly not for the musculoskeletal system reasons. In the same study, 61 percent of the cats had OA in not less than 
one joint, and 48 percent had over one joint affected [115]. Also, in the cats that were aged more than 14 years, 82 percent of them had OA in one joint in any case. Thus, the prevalence of OA in those cats was found to significantly increase with age. Per that data, a randomly selected sample of 100 cats aged up to 20 years old showed that nearly all of the cats (92\%) had radiographic evidence of different types of joint disease and that $91 \%$ had as a minimum of one site of appendicular joint disorder [110].

\section{UC-II Usage in Cats}

While treatment choices for cats with OA are limited due to their sensitivity to NSAIDs compared to dogs, a novel joint supplement containing $10 \mathrm{mg}$ UC-II was tested in the cats in accordance to what was assumed to decrease inflammation related to feline OA through oral tolerance, by which the immune reaction to antigens is reduced through a chronic presentation of the antigen to the GALT. The supplement was tested to measure the level of palatability and explore the tolerability levels of UC-II. For this purpose, 33 healthy cats of both genders were given one chewable UC-II containing tablet for 40 days, and at the end of the study, the observations reported. According to the data, the majority of the cats (more than 70\%) in the aforementioned study consumed the chewable UC-II-containing tablets, which were well tolerated [77].

\section{UC-II, Safety, Efficacy, and Adverse Effects}

Collagen fibrils form the structural basis of the cartilage matrix and are primarily consisted of type II collagen [46]. Collagen hydrolysate is determined by the enzymatic hydrolysis of collagenous tissues, such as bone and cartilage, and from animals such as chicken and fish, although has generally been accepted as a nontoxic food component by regulatory agencies [116,117]. The key feature of UC-II is its composition of amino acids, which provide the high levels of glycine and proline, the two essential amino acids for the stability and renewal of the cartilage tissue [118]. UC-II was reported to show intact tertiary and quaternary glycoprotein integrity, which allows the epitope recognition and hypo-responsive immune stimulation, whereas the denatured type II collagen contains no tertiary or quaternary glycoprotein integrity (Figure 3) [49]. Additionally, it has been mostly derived from chicken sternum as $40 \mathrm{mg}$ of UC-II material that provides $10.4 \pm 1.3 \mathrm{mg}$ of native type II collagen, which was encapsulated an opaque capsule with excipients [75]. A combination of radiology and histology techniques demonstrated that treatment with UC-II limits the size of the osteophytes and potentially supports the mobility and functionality of joints [17]. The structural integrity of undenatured type II collagen as an active UC-II sample was determined by a transmission electron microscope (Figure 3), while the amount of undenatured type II was characterized by ELISA [49].

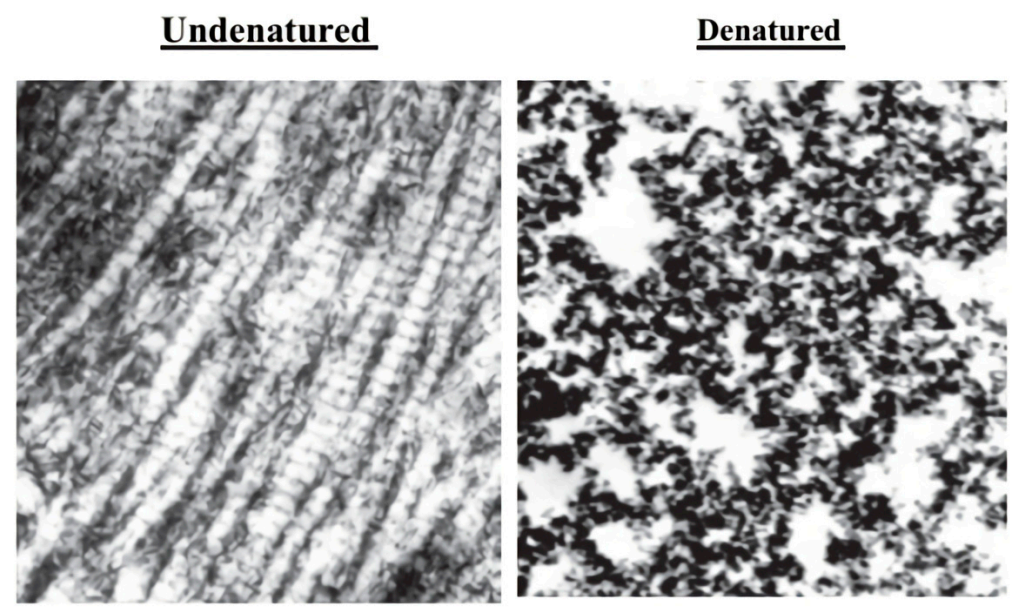

Figure 3. Electron micrographs of undenatured (UC-II) and denatured collagen II $(\times 50,000)[49]$. 
UC-II involved the undenatured native chicken type II collagen (collagen $263.0 \mathrm{mg} / \mathrm{g}$, hydroxyproline $32.9 \mathrm{mg} / \mathrm{g}$ ), which was produced from chicken sternum cartilage in a GMP-certified facility via a patented, low-temperature manufacturing process that ensured a specific level of UC-II collagen [17]. In a recent letter, the novel faster-produced commercially available UC-II ${ }^{\circledR}$ ingredient was reported to be identical with the material used in the previously published clinical research $[75,76,119]$. Several undenatured type II collagen, including UC-II ${ }^{\circledR}$, is a patented form of collagen with undenatured type II collagen for joint health support. It has been reported that a small amount $(40 \mathrm{mg} /$ day) is believed to work by inducing a process known as oral tolerance that ultimately engages the immune system in the repair of its joint cartilage [74]. Earlier studies have presented that small doses of UC-II modulate joint health in both OA and RA [49]. Marone et al. [120] also reported that UC-II has an acute oral LD50 greater than $5.000 \mathrm{mg} / \mathrm{kg}$ and an acute dermal LD50 greater than $2000 \mathrm{mg} / \mathrm{kg}$. UC-II is categorized as a mild irritant to the skin and moderately irritating to the eye based on primary skin and eye irritation tests. UC-II did not induce mutagenicity in the bacterial reverse mutation test in five Salmonella typhimurium strains, either with or without metabolic activation [120]. Similarly, UC-II did not produce a mutagenic effect in the gene mutation test in mouse lymphoma cells either with or without metabolic activation. A 90-day dose-dependent sub-chronic toxicity study in Sprague-Dawley rats showed no pathologically significant alterations in the selected organ weights individually or as a percentage of body or brain weights for oral intake of $400 \mathrm{mg} / \mathrm{kg}$ UC-II. They also reported that no important alterations were observed in hematology and clinical chemistry. Besides, it was also reported that UC-II is nontoxic for human consumption and affirmed its status as generally recognized as safe (GRAS) food ingredient [121]. Yoshinari et al. [99] also conducted a study to determine the broad-spectrum safety of new, water-soluble, undenatured type II collagen (NEXT-II) derived from chicken sternum cartilage. They reported that the acute oral $\mathrm{LD}_{50}$ of NEXT-II was greater than $5000 \mathrm{mg} / \mathrm{kg} \mathrm{BW}$ in rats, whereas single-dose acute dermal $\mathrm{LD}_{50}$ was greater than $2000 \mathrm{mg} / \mathrm{kg}$ BW and the primary dermal irritation index (PDII) of NEXT-II was found to be 1.8 and the skin was classified as a mild irritant. In primary eye irritation research, the maximum mean total score (MMTS) of NEXT-II was found to be 7.3 and classified as minimally irritant to the eye. Long-term safety studies were performed in dogs for 150 days, and no important alterations in blood chemistry, body weight, heart rate, and respiration rate were observed. No increase in biologically significant mutagenicity and no dose-related toxicity was reported [99]. In an experimental OA model of rats, UC-II has been shown to recover the mechanical function of the injured knee and inhibit extreme degeneration of the articular cartilage [17]. Additionally, in 90 days of toxicity study of the rabbits, no pathologically important change found in the organ weights as percentages of body or brain weights, without any substantial alteration of hematology and clinical chemistry, which verified a wide-spectrum safety profile of UC-II [120].

\section{Conclusions}

UC-II administration has been reported to be more effective than the most frequently used glucosamine and chondroitin sulfate supplements in joint health studies that were done with humans and animals. UC-II can alleviate inflammatory T-cell response and activate T-regulatory cells via its oral tolerance mechanism, which eventually may reduce the cartilage damage. While NSAIDs have been shown to induce several side effects, including GI bleeding, along with the renal and hepatic dysfunction causing problems, in the long run, it is obvious that a safe and effective therapy is needed. In order to shed light to the true mechanism of action that UC-II takes place in the articular cartilage, along with an intention to bring better insights to the joint repair mechanisms, the techniques such as immunohistochemically staining and the unchecked gene expression of peptides related to cartilage metabolism should be performed in the experimental small animal models of OA. In the current literature, UC-II has been suggested as a safe and effective supplement for joint health both for humans and animals. It has been and can further be used standalone or as an adjuvant therapy with drugs in the OA management of those suffering companion animals. 
Author Contributions: Conceptualization, K.S.; methodology, H.G. and C.O.; software, H.G. and E.S.; validation, K.S., C.O., and H.G.; investigation, H.G. and E.S.; writing-original draft preparation, H.G.; writing-review and editing, K.S.; visualization, H.G. and E.S.; supervision, K.S. All authors have read and agreed to the published version of the manuscript.

Funding: This research was funded by the Turkish Academy of Science (Ankara, Turkey).

Acknowledgments: This work was supported in part by the Turkish Academy of Science (KS, Ankara, Turkey).

Conflicts of Interest: The authors declare no conflict of interest.

\section{References}

1. Barbosa, J.D.; Lima, D.H.S.; Belo-Reis, A.S.; Pinheiro, C.P.; Sousa, M.G.S.; Silva, J.B.; Salvarani, F.M.; Oliveira, C.M.C. Degenerative joint disease in cattle and buffaloes in the Amazon region: A retrospective study. Pesqui. Vet. Bras. 2014, 34, 845-850. [CrossRef]

2. Iagnocco, A. Chapter 14-Osteoarthritis. In Essential Applications of Musculoskeletal Ultrasound in Rheumatology; Wakefield, R.J., D'Agostino, M.A., Eds.; W.B. Saunders: Philadelphia, PA, USA, 2010; pp. 165-180. ISBN 978-1-4377-0127-2.

3. Neugebauer, V.; Han, J.S.; Adwanikar, H.; Fu, Y.; Ji, G. Techniques for assessing knee joint pain in arthritis. Mol. Pain 2007, 3, 8. [CrossRef] [PubMed]

4. Serra, C.I.; Soler, C. Animal models of osteoarthritis in small mammals. Vet. Clin. N. Am. Exot. Anim. Pract. 2019, 22, 211-221. [CrossRef] [PubMed]

5. McLaughlin, R.M. Hind limb lameness in the young patient. Vet. Clin. N. Am. Small Anim. Pract. 2001, 31, 101-123. [CrossRef]

6. Ruff, K.J.; Kopp, K.J.; Von Behrens, P.; Lux, M.; Mahn, M.; Back, M. Effectiveness of NEM ${ }^{\circledR}$ brand eggshell membrane in the treatment of suboptimal joint function in dogs: A multicenter, randomized, double-blind, placebo-controlled study. Vet. Med. Res. Rep. 2016, 7, 113-121. [CrossRef]

7. Cimino Brown, D. What can we learn from osteoarthritis pain in companion animals? Clin. Exp. Rheumatol. 2017, 35 (Suppl. 107), 53-58.

8. Schachner, E.R.; Lopez, M.J. Diagnosis, prevention, and management of canine hip dysplasia: A review. Vet. Med. Res. Rep. 2015, 6, 181-192.

9. O'Neill, D.G.; Church, D.B.; McGreevy, P.D.; Thomson, P.C.; Brodbelt, D.C. Prevalence of disorders recorded in dogs attending primary-care veterinary practices in England. PLoS ONE 2014, 9, e90501. [CrossRef] [PubMed]

10. Guedes, A.G.P.; Meadows, J.M.; Pypendop, B.H.; Johnson, E.G. Evaluation of tramadol for treatment of osteoarthritis in geriatric cats. J. Am. Vet. Med. Assoc. 2018, 252, 565-571. [CrossRef] [PubMed]

11. Contino, E.K. Management and rehabilitation of joint disease in sport horses. Vet. Clin. N. Am. Equine Pract. 2018, 34, 345-358. [CrossRef]

12. Anderson, K.L.; O’Neill, D.G.; Brodbelt, D.C.; Church, D.B.; Meeson, R.L.; Sargan, D.; Summers, J.F.; Zulch, H.; Collins, L.M. Prevalence, duration and risk factors for appendicular osteoarthritis in a UK dog population under primary veterinary care. Sci. Rep. 2018, 8. [CrossRef] [PubMed]

13. Bland, S.D. Canine osteoarthritis and treatments: A review. Vet. Sci. Dev. 2015. [CrossRef]

14. Chen, D.; Shen, J.; Zhao, W.; Wang, T.; Han, L.; Hamilton, J.L.; Im, H.-J. Osteoarthritis: Toward a comprehensive understanding of pathological mechanism. Bone Res. 2017, 5, 16044. [CrossRef] [PubMed]

15. Mobasheri, A.; Batt, M. An update on the pathophysiology of osteoarthritis. Ann. Phys. Rehabil. Med. 2016, 59, 333-339. [CrossRef]

16. Henrotin, Y.; Sanchez, C.; Balligand, M. Pharmaceutical and nutraceutical management of canine osteoarthritis: Present and future perspectives. Vet. J. Lond. Engl. 1997 2005, 170, 113-123. [CrossRef]

17. Bagi, C.M.; Berryman, E.R.; Teo, S.; Lane, N.E. Oral administration of undenatured native chicken type II collagen (UC-II) diminished deterioration of articular cartilage in a rat model of osteoarthritis (OA). Osteoarthr. Cartil. 2017, 25, 2080-2090. [CrossRef]

18. Aragon, C.L.; Hofmeister, E.H.; Budsberg, S.C. Systematic review of clinical trials of treatments for osteoarthritis in dogs. J. Am. Vet. Med. Assoc. 2007, 230, 514-521. [CrossRef]

19. Beale, B. Orthopedic clinical techniques femur fracture repair. Clin. Technol. Small Anim. Pract. 2004, 19, 134-150. [CrossRef] 
20. D'Altilio, M.; Peal, A.; Alvey, M.; Simms, C.; Curtsinger, A.; Gupta, R.C.; Canerdy, T.D.; Goad, J.T.; Bagchi, M.; Bagchi, D. therapeutic efficacy and safety of undenatured type II collagen singly or in combination with glucosamine and chondroitin in arthritic dogs. Toxicol. Mech. Methods 2007, 17, 189-196. [CrossRef]

21. Prabhoo, R.; Billa, G. Undenatured collagen type II for the treatment of osteoarthritis: A review. Int. J. Res. Orthop. 2018, 4, 684-689. [CrossRef]

22. Martel-Pelletier, J.; Boileau, C.; Pelletier, J.-P.; Roughley, P.J. Cartilage in normal and osteoarthritis conditions. Best Pract. Res. Clin. Rheumatol. 2008, 22, 351-384. [CrossRef]

23. Collins, J.A.; Diekman, B.O.; Loeser, R.F. Targeting aging for disease modification in osteoarthritis. Curr. Opin. Rheumatol. 2018, 30, 101. [CrossRef]

24. Li, Y.-S.; Xiao, W.; Luo, W. Cellular aging towards osteoarthritis. Mech. Ageing Dev. 2017, 162, 80-84. [CrossRef]

25. Rahmati, M.; Nalesso, G.; Mobasheri, A.; Mozafari, M. Aging and osteoarthritis: Central role of the extracellular matrix. Ageing Res. Rev. 2017, 40, 20-30. [CrossRef]

26. Mobasheri, A.; Rayman, M.P.; Gualillo, O.; Sellam, J.; van der Kraan, P.; Fearon, U. The role of metabolism in the pathogenesis of osteoarthritis. Nat. Rev. Rheumatol. 2017, 13, 302-311. [CrossRef]

27. Yuan, G.-H.; Masuko-Hongo, K.; Kato, T.; Nishioka, K. Immunologic intervention in the pathogenesis of osteoarthritis. Arthritis Rheum. 2003, 48, 602-611. [CrossRef]

28. Poole, A.; Kobayashi, M.; Yasuda, T.; Laverty, S.; Mwale, F.; Kojima, T.; Sakai, T.; Wahl, C.; El-Maadawy, S.; Webb, G.; et al. Type II collagen degradation and its regulation in articular cartilage in osteoarthritis. Ann. Rheum. Dis. 2002, 61, ii78-ii81. [CrossRef]

29. Sandell, L.J.; Aigner, T. Articular cartilage and changes in Arthritis: Cell biology of osteoarthritis. Arthritis Res. 2001, 3, 107-113. [CrossRef]

30. Pelletier, J.-P.; Martel-Pelletier, J.; Abramson, S.B. Osteoarthritis, an inflammatory disease: Potential implication for the selection of new therapeutic targets. Arthritis Rheum. 2001, 44, 1237-1247. [CrossRef]

31. Abramson, S.B.; Attur, M.; Amin, A.R.; Clancy, R. Nitric oxide and inflammatory mediators in the perpetuation of osteoarthritis. Curr. Rheumatol. Rep. 2001, 3, 535-541. [CrossRef]

32. Amin, A.R.; Dave, M.; Attur, M.; Abramson, S.B. COX-2, NO, and cartilage damage and repair. Curr. Rheumatol. Rep. 2000, 2, 447-453. [CrossRef]

33. Moreland, L.W. Intra-articular hyaluronan (hyaluronic acid) and hylans for the treatment of osteoarthritis: Mechanisms of action. Arthritis Res Ther. 2003, 5, 54. [CrossRef]

34. Mehana, E.-S.E.; Khafaga, A.F.; El-Blehi, S.S. The role of matrix metalloproteinases in osteoarthritis pathogenesis: An updated review. Life Sci. 2019, 234, 116786. [CrossRef]

35. Nagase, H.; Kashiwagi, M. Aggrecanases and cartilage matrix degradation. Arthritis Res. Ther. 2003, 5, 94. [CrossRef]

36. Poole, A.R. An introduction to the pathophysiology of osteoarthritis. Front. Biosci. J. Virtual Libr. 1999, 4, D662-D670. [CrossRef]

37. Pelletier, J.P.; Caron, J.P.; Evans, C.; Robbins, P.D.; Georgescu, H.I.; Jovanovic, D.; Fernandes, J.C.; Martel-Pelletier, J. In vivo suppression of early experimental osteoarthritis by interleukin-1 receptor antagonist using gene therapy. Arthritis Rheum. 1997, 40, 1012-1019. [CrossRef]

38. Cicero, A.F.; Laghi, L. Activity and potential role of licofelone in the management of osteoarthritis. Clin. Interv. Aging 2007, 2, 73-79. [CrossRef]

39. Pelletier, J.-P.; Boileau, C.; Boily, M.; Brunet, J.; Mineau, F.; Geng, C.; Reboul, P.; Laufer, S.; Lajeunesse, D.; Martel-Pelletier, J. The protective effect of licofelone on experimental osteoarthritis is correlated with the downregulation of gene expression and protein synthesis of several major cartilage catabolic factors: MMP-13, cathepsin K and aggrecanases. Arthritis Res. Ther. 2005, 7, R1091-R1102. [CrossRef]

40. Jovanovic, D.V.; Fernandes, J.C.; Martel-Pelletier, J.; Jolicoeur, F.C.; Reboul, P.; Laufer, S.; Tries, S.; Pelletier, J.P. In vivo dual inhibition of cyclooxygenase and lipoxygenase by ML-3000 reduces the progression of experimental osteoarthritis: Suppression of collagenase 1 and interleukin-1beta synthesis. Arthritis Rheum. 2001, 44, 2320-2330. [CrossRef]

41. Zhang, W.; Ouyang, H.; Dass, C.R.; Xu, J. Current research on pharmacologic and regenerative therapies for osteoarthritis. Bone Res. 2016, 4, 15040. [CrossRef]

42. Jafarzadeh, S.R.; Felson, D.T. Updated estimates suggest a much higher prevalence of arthritis in United States adults than previous ones. Arthritis Rheumatol. 2018, 70, 185-192. [CrossRef] 
43. Bhathal, A.; Spryszak, M.; Louizos, C.; Frankel, G. Glucosamine and chondroitin use in canines for osteoarthritis: A review. Open Vet. J. 2017, 7, 36. [CrossRef]

44. Liu, X.; Machado, G.C.; Eyles, J.P.; Ravi, V.; Hunter, D.J. Dietary supplements for treating osteoarthritis: A systematic review and meta-analysis. Br. J. Sports Med. 2018, 52, 167-175. [CrossRef]

45. Sahin, K.; Perez Ojalvo, S.; Akdemir, F.; Orhan, C.; Tuzcu, M.; Sahin, N.; Ozercan, I.H.; Sylla, S.; Koca, S.S.; Yilmaz, I.; et al. Effect of inositol -stabilized arginine silicate on arthritis in a rat model. Food Chem. Toxicol. Int. J. Publ. Br. Ind. Biol. Res. Assoc. 2019, 125, 242-251. [CrossRef]

46. Sophia Fox, A.J.; Bedi, A.; Rodeo, S.A. The basic science of articular cartilage. Sports Health 2009, 1, 461-468. [CrossRef]

47. Pelletier, J.-P.; Martel-Pelletier, J.; Raynauld, J.-P. Most recent developments in strategies to reduce the progression of structural changes in osteoarthritis: Today and tomorrow. Arthritis Res. Ther. 2006, 8, 206. [CrossRef]

48. Gordon, M.K.; Hahn, R.A. Collagens. Cell Tissue Res. 2010, 339, 247-257. [CrossRef]

49. Bagchi, D.; Misner, B.; Bagchi, M.; Kothari, S.C.; Downs, B.W.; Fafard, R.D.; Preuss, H.G. Effects of orally administered undenatured type II collagen against arthritic inflammatory diseases: A mechanistic exploration. Int. J. Clin. Pharmacol. Res. 2002, 22, 101-110.

50. Lerman, R.H.; Chang, J.-L.; Konda, V.; Desai, A.; Montalto, M.B. Nutritional approach for relief of joint discomfort: A 12-week, open-case series and illustrative case report. Integr. Med. 2015, 14, 10.

51. Tong, T.; Zhao, W.; Wu, Y.-Q.; Chang, Y.; Wang, Q.-T.; Zhang, L.-L.; Wei, W. Chicken type II collagen induced immune balance of main subtype of helper $\mathrm{T}$ cells in mesenteric lymph node lymphocytes in rats with collagen-induced arthritis. Inflamm. Res. Off. J. Eur. Histamine Res. Soc. 2010, 59, 369-377. [CrossRef]

52. Nagler-Anderson, C.; Bober, L.A.; Robinson, M.E.; Siskind, G.W.; Thorbecke, G.J. Suppression of type II collagen-induced arthritis by intragastric administration of soluble type II collagen. Proc. Natl. Acad. Sci. USA 1986, 83, 7443-7446. [CrossRef]

53. Asnagli, H.; Martire, D.; Belmonte, N.; Quentin, J.; Bastian, H.; Boucard-Jourdin, M.; Fall, P.B.; Mausset-Bonnefont, A.-L.; Mantello-Moreau, A.; Rouquier, S.; et al. Type 1 regulatory T cells specific for collagen type II as an efficient cell-based therapy in arthritis. Arthritis Res. Ther. 2014, 16, R115. [CrossRef]

54. Müller, R.D.; John, T.; Kohl, B.; Oberholzer, A.; Gust, T.; Hostmann, A.; Hellmuth, M.; Laface, D.; Hutchins, B.; Laube, G.; et al. IL-10 overexpression differentially affects cartilage matrix gene expression in response to TNF-alpha in human articular chondrocytes in vitro. Cytokine 2008, 44, 377-385. [CrossRef]

55. Steinmeyer, J. Pharmacological basis for the therapy of pain and inflammation with nonsteroidal anti-inflammatory drugs. Arthritis Res. 2000, 2, 379-385. [CrossRef]

56. Marshall, S.; Bacote, V.; Traxinger, R.R. Discovery of a metabolic pathway mediating glucose-induced desensitization of the glucose transport system. Role of hexosamine biosynthesis in the induction of insulin resistance. J. Biol. Chem. 1991, 266, 4706-4712.

57. Simon, R.R.; Marks, V.; Leeds, A.R.; Anderson, J.W. A comprehensive review of oral glucosamine use and effects on glucose metabolism in normal and diabetic individuals. Diabetes Metab. Res. Rev. 2011, 27, 14-27. [CrossRef]

58. Patti, M.E.; Virkamäki, A.; Landaker, E.J.; Kahn, C.R.; Yki-Järvinen, H. Activation of the hexosamine pathway by glucosamine in vivo induces insulin resistance of early postreceptor insulin signaling events in skeletal muscle. Diabetes 1999, 48, 1562-1571. [CrossRef]

59. Rossetti, L.; Hawkins, M.; Chen, W.; Gindi, J.; Barzilai, N. In vivo glucosamine infusion induces insulin resistance in normoglycemic but not in hyperglycemic conscious rats. J. Clin. Investig. 1995, 96, 132-140. [CrossRef]

60. Ando, A.; Hagiwara, Y.; Chimoto, E.; Hatori, K.; Onoda, Y.; Itoi, E. Intra-articular injection of hyaluronan diminishes loss of chondrocytes in a rat immobilized-knee model. Tohoku J. Exp. Med. 2008, 215, 321-331. [CrossRef]

61. Rausch-Derra, L.; Huebner, M.; Wofford,J.; Rhodes, L. A prospective, randomized, masked, placebo-controlled multisite clinical study of grapiprant, an EP4 Prostaglandin Receptor Antagonist (PRA), in dogs with osteoarthritis. J. Vet. Intern. Med. 2016, 30, 756-763. [CrossRef]

62. Bergh, M.S.; Budsberg, S.C. The coxib NSAIDs: Potential clinical and pharmacologic importance in veterinary medicine. J. Vet. Intern. Med. 2005, 19, 633-643. [CrossRef] 
63. KuKanich, B.; Bidgood, T.; Knesl, O. Clinical pharmacology of nonsteroidal anti-inflammatory drugs in dogs. Vet. Anaesth. Analg. 2012, 39, 69-90. [CrossRef]

64. Ho, K.Y.; Gwee, K.A.; Cheng, Y.K.; Yoon, K.H.; Hee, H.T.; Omar, A.R. Nonsteroidal anti-inflammatory drugs in chronic pain: Implications of new data for clinical practice. J. Pain Res. 2018, 11, 1937-1948. [CrossRef]

65. Jerosch, J. Effects of glucosamine and chondroitin sulfate on cartilage metabolism in OA: Outlook on other nutrient partners especially omega-3 fatty acids. Int. J. Rheumatol. 2011, 2011, 969012. [CrossRef]

66. Copeland, R.J.; Bullen, J.W.; Hart, G.W. Cross-talk between GlcNAcylation and phosphorylation: Roles in insulin resistance and glucose toxicity. Am. J. Physiol. Endocrinol. Metab. 2008, 295, E17-E28. [CrossRef]

67. Zhou, P.-H.; Liu, S.-Q.; Peng, H. The effect of hyaluronic acid on IL-1beta-induced chondrocyte apoptosis in a rat model of osteoarthritis. J. Orthop. Res. Off. Publ. Orthop. Res. Soc. 2008, 26, 1643-1648. [CrossRef]

68. Peal, A.; D'Altilio, M.; Simms, C.; Alvey, M.; Gupta, R.C.; Goad, J.T.; Canerdy, T.D.; Bagchi, M.; Bagchi, D. Therapeutic efficacy and safety of undenatured type-II collagen (UC-II) alone or in combination with (-)-hydroxycitric acid and chromemate in arthritic dogs. J. Vet. Pharmacol. Ther. 2007, 30, 275-278. [CrossRef]

69. Deparle, L.A.; Gupta, R.C.; Canerdy, T.D.; Goad, J.T.; D'Altilio, M.; Bagchi, M.; Bagchi, D. Efficacy and safety of glycosylated undenatured type-II collagen (UC-II) in therapy of arthritic dogs. J. Vet. Pharmacol. Ther. 2005, 28, 385-390. [CrossRef]

70. Bagchi, M.; Stocker, A.; Burke, R.; Wedgeford, K.; Gupta, R.C.; Canerdy, T.D.; Goad, J.T.; Barnett, D.; Bagchi, D. Efficacy and safety of undenatured type II collagen (UC-II) in arthritic horses. Toxicol. Lett. 2007, 172, S223. [CrossRef]

71. Crowley, D.C.; Lau, F.C.; Sharma, P.; Evans, M.; Guthrie, N.; Bagchi, M.; Bagchi, D.; Dey, D.K.; Raychaudhuri, S.P. Safety and efficacy of undenatured type II collagen in the treatment of osteoarthritis of the knee: A clinical trial. Int. J. Med. Sci. 2009, 312-321. [CrossRef]

72. Gupta, R.C.; Canerdy, T.D.; Skaggs, P.; Stocker, A.; Zyrkowski, G.; Burke, R.; Wegford, K.; Goad, J.T.; Rohde, K.; Barnett, D.; et al. Therapeutic efficacy of undenatured type-II collagen (UC-II) in comparison to glucosamine and chondroitin in arthritic horses. J. Vet. Pharmacol. Ther. 2009, 32, 577-584. [CrossRef]

73. Bagchi, M.; Gupta, R.; Lindley, J.; Barnes, M.; Canerdy, T.; Goad, J.; Bagchi, D. Suppression of arthritic pain in dogs by undenatured type-II collagen (UC-II) treatment quantitatively assessed by ground force plate. Toxicol. Lett. 2009, 189, S231. [CrossRef]

74. Gupta, R.C.; Canerdy, T.D.; Lindley, J.; Konemann, M.; Minniear, J.; Carroll, B.A.; Hendrick, C.; Goad, J.T.; Rohde, K.; Doss, R.; et al. Comparative therapeutic efficacy and safety of type-II collagen (uc-II), glucosamine and chondroitin in arthritic dogs: Pain evaluation by ground force plate: Arthritis treatment in dogs. J. Anim. Physiol. Anim. Nutr. 2012, 96, 770-777. [CrossRef]

75. Lugo, J.P.; Saiyed, Z.M.; Lau, F.C.; Molina, J.P.L.; Pakdaman, M.N.; Shamie, A.; Udani, J.K. Undenatured type II collagen (UC-II $\left.{ }^{\circledR}\right)$ for joint support: A randomized, double-blind, placebo-controlled study in healthy volunteers. J. Int. Soc. Sports Nutr. 2013, 10, 48. [CrossRef]

76. Lugo, J.P.; Saiyed, Z.M.; Lane, N.E. Efficacy and tolerability of an undenatured type II collagen supplement in modulating knee osteoarthritis symptoms: A multicenter randomized, double-blind, placebo-controlled study. Nutr. J. 2015, 15, 14. [CrossRef]

77. Blair, J.L.; Bonavaud, S. Palatability and tolerability of a novel joint supplement in the cat. Clinical/research abstracts accepted for presentation at the World Feline Congress 2017. J. Feline Med. Surg. 2017, 19, 961-969.

78. Samarelli, R.; Stabile, M.; Fracassi, L. Use of UC-II (Undenaturated Type II Collagen) in Management of Osteoarthritis in Dogs: A Clinical Trial; Università degli Studi: Torino, Italy, 2018.

79. Stabile, M.; Samarelli, R.; Trerotoli, P.; Fracassi, L.; Lacitignola, L.; Crovace, A.; Staffieri, F. Evaluation of the effects of undenatured type II collagen (UC-II) as compared to robenacoxib on the mobility impairment induced by osteoarthritis in dogs. Vet. Sci. 2019, 6, 72. [CrossRef]

80. Mehra, A.; Anand, P.; Borate, M.; Paul, P.; Kamble, S.; Mehta, K.D.; Qamra, A.; Shah, A.; Jain, R. A non-interventional, prospective, multicentric real life Indian study to assess safety and effectiveness of un-denatured type 2 collagen in management of osteoarthritis. Int. J. Res. Orthop. 2019, 5, 315-320. [CrossRef]

81. Azeem, M.A.; Patil, R. The Study of undenatured type II collagen in the knee osteoarthritis. Int. J. Orthop. 2019, 5, 4 .

82. Meeson, R.L.; Todhunter, R.J.; Blunn, G.; Nuki, G.; Pitsillides, A.A. Spontaneous dog osteoarthritis-A One Medicine vision. Nat. Rev. Rheumatol. 2019, 15, 273-287. [CrossRef] 
83. King, L.K.; March, L.; Anandacoomarasamy, A. Obesity \& osteoarthritis. Indian J. Med. Res. 2013, 138, 185-193.

84. Man, G.; Mologhianu, G. Osteoarthritis pathogenesis-A complex process that involves the entire joint. J. Med. Life 2014, 7, 37-41.

85. Grandalen, J.; Lingaas, F. Arthrosis in the elbow joint of young rapidly growing dogs: A genetic investigation. J. Small Anim. Pract. 1991, 32, 460-464. [CrossRef]

86. Alam, M.R.; Lee, H.B.; Kim, M.S.; Kim, N. Surgical model of osteoarthritis secondary to medial patellar luxation in dogs. Vet. Med. 2018, 53, 123-130. [CrossRef]

87. Rychel, J.K. Diagnosis and treatment of osteoarthritis. Top. Companion Anim. Med. 2010, 25, 20-25. [CrossRef]

88. Mele, E. Epidemiology of osteoarthritis. Vet. Focus 2007, 17, 4-10. [CrossRef]

89. Pettitt, R.A.; German, A.J. Investigation and management of canine osteoarthritis. Practice 2015, 37, 1-8. [CrossRef]

90. Smith, G.K.; Paster, E.R.; Powers, M.Y.; Lawler, D.F.; Biery, D.N.; Shofer, F.S.; McKelvie, P.J.; Kealy, R.D. Lifelong diet restriction and radiographic evidence of osteoarthritis of the hip joint in dogs. J. Am. Vet. Med. Assoc. 2006, 229, 690-693. [CrossRef]

91. Johnston, S.A. Osteoarthritis. Joint anatomy, physiology, and pathobiology. Vet. Clin. N. Am. Small Anim. Pract. 1997, 27, 699-723. [CrossRef]

92. Goh, S.-L.; Persson, M.S.M.; Stocks, J.; Hou, Y.; Welton, N.J.; Lin, J.; Hall, M.C.; Doherty, M.; Zhang, W. Relative efficacy of different exercises for pain, function, performance and quality of life in knee and hip osteoarthritis: Systematic review and network meta-analysis. Sports Med. 2019, 49, 743-761. [CrossRef]

93. Lascelles, B.D.X.; Knazovicky, D.; Case, B.; Freire, M.; Innes, J.F.; Drew, A.C.; Gearing, D.P. A canine-specific anti-nerve growth factor antibody alleviates pain and improves mobility and function in dogs with degenerative joint disease-associated pain. BMC Vet. Res. 2015, 11, 101. [CrossRef] [PubMed]

94. Comblain, F.; Serisier, S.; Barthelemy, N.; Balligand, M.; Henrotin, Y. Review of dietary supplements for the management of osteoarthritis in dogs in studies from 2004 to 2014. J. Vet. Pharmacol. Ther. 2016, 39, 1-15. [CrossRef]

95. Sieper, J.; Kary, S.; Sörensen, H.; Alten, R.; Eggens, U.; Hüge, W.; Hiepe, F.; Kühne, A.; Listing, J.; Ulbrich, N.; et al. Oral type II collagen treatment in early rheumatoid arthritis. A double-blind, placebo-controlled, randomized trial. Arthritis Rheum. 1996, 39, 41-51. [CrossRef]

96. Trentham, D.E.; Dynesius-Trentham, R.A.; Orav, E.J.; Combitchi, D.; Lorenzo, C.; Sewell, K.L.; Hafler, D.A.; Weiner, H.L. Effects of oral administration of type II collagen on rheumatoid arthritis. Science 1993, 261, 1727-1730. [CrossRef] [PubMed]

97. Park, K.-S.; Park, M.-J.; Cho, M.-L.; Kwok, S.-K.; Ju, J.H.; Ko, H.-J.; Park, S.-H.; Kim, H.-Y. Type II collagen oral tolerance; mechanism and role in collagen-induced arthritis and rheumatoid arthritis. Mod. Rheumatol. 2009, 19, 581-589. [CrossRef] [PubMed]

98. Yoshinari, O.; Moriyama, H.; Shiojima, Y. An overview of a novel, water-soluble undenatured type II collagen (NEXT-II). J. Am. Coll. Nutr. 2015, 34, 255-262. [CrossRef]

99. Yoshinari, O.; Shiojima, Y.; Moriyama, H.; Shinozaki, J.; Nakane, T.; Masuda, K.; Bagchi, M. Water-soluble undenatured type II collagen ameliorates collagen-induced arthritis in mice. J. Med. Food 2013, 16, 1039-1045. [CrossRef]

100. Caron, J.P. Chapter 63-Osteoarthritis. In Diagnosis and Management of Lameness in the Horse; Ross, M.W., Dyson, S.J., Eds.; W.B. Saunders: Saint Louis, MO, USA, 2003; pp. 572-591. ISBN 978-0-7216-8342-3.

101. Ireland, J.L.; Wylie, C.E.; Collins, S.N.; Verheyen, K.L.P.; Newton, J.R. Preventive health care and owner-reported disease prevalence of horses and ponies in Great Britain. Res. Vet. Sci. 2013, 95, 418-424. [CrossRef]

102. Van Weeren, P.R.; Back, W. Musculoskeletal disease in aged horses and its management. Vet. Clin. N. Am. Equine Pract. 2016, 32, 229-247. [CrossRef]

103. Da Garcia, R.S.; de Melo, U.P.; Ferreira, C.; dos Toscano, F.S.; da Cruz, G.M. Estudo clínico e radiográfico da osteoartrite társica juvenil em potros da raça mangalarga marchador. Ciênc. Anim. Bras. 2009, 10, 254-260.

104. Kawcak, C.E.; McIlwraith, C.W.; Norrdin, R.W.; Park, R.D.; James, S.P. The role of subchondral bone in joint disease: A review. Equine Vet. J. 2001, 33, 120-126. [CrossRef] [PubMed]

105. Riggs, C.M.; Whitehouse, G.H.; Boyde, A. Pathology of the distal condyles of the third metacarpal and third metatarsal bones of the horse. Equine Vet. J. 1999, 31, 140-148. [CrossRef] [PubMed] 
106. Neundorf, R.H.; Lowerison, M.B.; Cruz, A.M.; Thomason, J.J.; McEwen, B.J.; Hurtig, M.B. Determination of the prevalence and severity of metacarpophalangeal joint osteoarthritis in Thoroughbred racehorses via quantitative macroscopic evaluation. Am. J. Vet. Res. 2010, 71, 1284-1293. [CrossRef] [PubMed]

107. Egenvall, A.; Penell, J.C.; Bonnett, B.N.; Olson, P.; Pringle, J. Mortality of Swedish horses with complete life insurance between 1997 and 2000: Variations with sex, age, breed and diagnosis. Vet. Rec. 2006, 158, 397-406. [CrossRef] [PubMed]

108. Klinck, M.P.; Frank, D.; Guillot, M.; Troncy, E. Owner-perceived signs and veterinary diagnosis in 50 cases of feline osteoarthritis. Can. Vet. J. 2012, 53, 1181-1186. [PubMed]

109. Stamper, C. Osteoarthritis in cats: A more common disease than you might expect. FDA 2008, 23, 6-8.

110. Lascelles, B.D.X. Feline degenerative joint disease. Vet. Surg. 2010, 39, 2-13. [CrossRef]

111. Bennett, D.; Zainal Ariffin, S.M.; Johnston, P. Osteoarthritis in the cat: 1 . how common is it and how easy to recognise? J. Feline Med. Surg. 2012, 14, 65-75. [CrossRef]

112. Clarke, S.P.; Mellor, D.; Clements, D.N.; Gemmill, T.; Farrell, M.; Carmichael, S.; Bennett, D. Prevalence of radiographic signs of degenerative joint disease in a hospital population of cats. Vet. Rec. 2005, 157, 793-799. [CrossRef]

113. Godfrey, D.R. Osteoarthritis in cats: A retrospective radiological study. J. Small Anim. Pract. 2005, 46, 425-429. [CrossRef]

114. Hardie, E.M.; Roe, S.C.; Martin, F.R. Radiographic evidence of degenerative joint disease in geriatric cats: 100 cases (1994-1997). J. Am. Vet. Med. Assoc. 2002, 220, 628-632. [CrossRef] [PubMed]

115. Slingerland, L.I.; Hazewinkel, H.W.; Meij, B.P.; Picavet, P.; Voorhout, G. Cross-sectional study of the prevalence and clinical features of osteoarthritis in 100 cats. Vet. J. Lond. Engl. 1997 2011, 187, 304-309. [CrossRef]

116. Schadow, S.; Siebert, H.-C.; Lochnit, G.; Kordelle, J.; Rickert, M.; Steinmeyer, J. Collagen metabolism of human osteoarthritic articular cartilage as modulated by bovine collagen hydrolysates. PLoS ONE 2013, 8, e53955. [CrossRef] [PubMed]

117. European Food Safety Authority (EFSA). Opinion of the Scientific Panel on biological hazards (BIOHAZ) on the safety of collagen and a processing method for the production of collagen. EFSA J. 2005, 3, 174. [CrossRef]

118. Walrand, S.; Chiotelli, E.; Noirt, F.; Mwewa, S.; Lassel, T. Consumption of a functional fermented milk containing collagen hydrolysate improves the concentration of collagen-specific amino acids in plasma. J. Agric. Food Chem. 2008, 56, 7790-7795. [CrossRef] [PubMed]

119. Lugo, J.P. Letter to the editor UC-II ${ }^{\circledR}$ Undenatured type II collagen: Update to analytical methods. J. Int. Soc. Sports Nutr. 2019, 16, 29. [CrossRef] [PubMed]

120. Marone, P.A.; Lau, F.C.; Gupta, R.C.; Bagchi, M.; Bagchi, D. Safety and toxicological evaluation of undenatured type II collagen. Toxicol. Mech. Methods 2010, 20, 175-189. [CrossRef]

121. InterHealth's UC-IIßReceives GRAS Status. Available online: https://www.newhope.com/food-ampbeverage/interhealths-uc-ii-receives-gras-status (accessed on 14 October 2019). 